\title{
Chronic Morphine Treatment Impaired Hippocampal Long-Term Potentiation and Spatial Memory via Accumulation of Extracellular Adenosine Acting on Adenosine $\mathrm{A}_{1}$ Receptors
}

\author{
Gang Lu, ${ }^{1 \star}$ Qi-Xin Zhou, ${ }^{2 \star}$ Shuo Kang, ${ }^{1}$ Qing-Lin Li, ${ }^{3}$ Liang-Cai Zhao, ${ }^{3}$ Jia-Dong Chen, ${ }^{4}$ Jian-Feng Sun, ${ }^{1}$ Jun Cao, ${ }^{2}$ \\ Yu-Jun Wang, ${ }^{1}$ Jie Chen, ${ }^{1}$ Xiao-Yan Chen, ${ }^{1}$ Da-Fang Zhong, ${ }^{1}$ Zhi-Qiang Chi, ${ }^{1}$ Lin Xu, ${ }^{2}$ and Jing-Gen Liu ${ }^{1}$ \\ ${ }^{1}$ State Key Laboratory of Drug Research, Shanghai Institute of Materia Medica, Shanghai Institute For Biological Sciences, Chinese Academy of Sciences, \\ Shanghai 201203, China, ${ }^{2}$ Key Laboratory of Animal Models and Human Disease Mechanisms of Chinese Academy of Sciences \& Yunnan Province, \\ Kunming Institute of Zoology, Kunming, Yunnan 650223, China, ${ }^{3}$ Anhui University of Traditional Chinese Medicine, Hefei 230032, China, and ${ }^{4}$ State Key \\ Laboratory of Neuroscience, Institute of Neuroscience, Chinese Academy of Sciences, Shanghai 200031, China
}

Chronic exposure to opiates impairs hippocampal long-term potentiation (LTP) and spatial memory, but the underlying mechanisms remain to be elucidated. Given the well known effects of adenosine, an important neuromodulator, on hippocampal neuronal excitability and synaptic plasticity, we investigated the potential effect of changes in adenosine concentrations on chronic morphine treatmentinduced impairment of hippocampal CA1 LTP and spatial memory. We found that chronic treatment in mice with either increasing doses $(20-100 \mathrm{mg} / \mathrm{kg})$ of morphine for $7 \mathrm{~d}$ or equal daily dose $(20 \mathrm{mg} / \mathrm{kg})$ of morphine for $12 \mathrm{~d}$ led to a significant increase of hippocampal extracellular adenosine concentrations. Importantly, we found that accumulated adenosine contributed to the inhibition of the hippocampal CA1 LTP and impairment of spatial memory retrieval measured in the Morris water maze. Adenosine $\mathrm{A}_{1}$ receptor antagonist 8-cyclopentyl-1,3-dipropylxanthine significantly reversed chronic morphine-induced impairment of hippocampal CA1 LTP and spatial memory. Likewise, adenosine deaminase, which converts adenosine into the inactive metabolite inosine, restored impaired hippocampal CA1 LTP. We further found that adenosine accumulation was attributable to the alteration of adenosine uptake but not adenosine metabolisms. Bidirectional nucleoside transporters (ENT2) appeared to play a key role in the reduction of adenosine uptake. Changes in PKC- $\alpha / \beta$ activity were correlated with the attenuation of the ENT2 function in the short-term $(2 \mathrm{~h})$ but not in the long-term (7 $\mathrm{d})$ period after the termination of morphine treatment. This study reveals a potential mechanism by which chronic exposure to morphine leads to impairment of both hippocampal LTP and spatial memory.

\section{Introduction}

Opiate addiction is defined as compulsive use of opiates despite serious negative consequences (Hyman et al., 2006). Development of drug addiction has been proposed to be attributable to an aberrant form of learning and memory, mediated by maladaptive plasticity in the brain structures involved in learning and memory (Nestler and Aghajanian, 1997; Robbins and Everitt,

\footnotetext{
Received Jan. 11, 2010; revised Feb. 28, 2010; accepted March 3, 2010.

This study was supported by National Basic Research Program grants from the Ministry of Science and Technology of China (G2003CB515400, 2009CB522000, and 2009ZX09301-001 to J.-G.L.; and 2006CB500808 to L.X.), the National Science Fund for Distinguished Young Scholars from the National Natural Science Foundation of China (30425002 to J.-G.L.), the National Science Fund of China (30873050 to J.-G.L., 30530250 to L.X.) and a grant from the Chinese Academy of Sciences (KSCXI/YW/R/68 to J.-G.L. and L.X.).

${ }^{*} G$.L. and Q.-X.Z. contributed equally to this work.

Correspondence should be addressed to either of the following: Dr. Jing-Gen Liu, State Key Laboratory of Drug Research, Shanghai Institute of Materia Medica, Shanghai Institutes for Biological Sciences, Chinese Academy of Sciences, Shanghai 201203, China, E-mail: jgliu@mail.shcnc.ac.cn; or Dr. Lin Xu, Key Laboratory of Animal Models and Human Disease Mechanisms of Chinese Academy of Sciences \& Yunnan Province, Kunming Institute of Zoology, Kunming, Yunnan 650223, China, E-mail: Ixu@vip.163.com.

DOI:10.1523/JNEUROSCI.0148-10.2010

Copyright $\odot 2010$ the authors $\quad 0270-6474 / 10 / 305058-13 \$ 15.00 / 0$
}

1999; Eisch et al., 2000; Kelley et al., 2000). There is some evidence that chronic exposure to opiates (e.g., morphine and heroin) can impair long-term potentiation (LTP), a form of plasticity that is considered as a possible basis for learning and memory in the brain (Bliss and Collingridge, 1993) and cause cognitive deficits (Cipolli and Galliani, 1987; Guerra et al., 1987; Spain and Newsom, 1991), which may be associated with behavioral abnormalities of opiate addiction.

The hippocampus is a brain region associated with learning and memory (Everitt and Robbins, 1997). Accumulating evidence demonstrates that it also plays a role in opioid dependence (Done et al., 1992; Fan et al., 1999; Lu et al., 2000; Rezayof et al., 2003). Several studies have shown that chronic exposure to morphine or heroin leads to the impairment of hippocampal LTP $(\mathrm{Pu}$ et al., 2002; Salmanzadeh et al., 2003; Bao et al., 2007) and induces cognitive deficits, as shown by poor performances on memory task of heroin abusers (Guerra et al., 1987) or chronic opiatetreated rodents (Spain and Newsom, 1991; Li et al., 2001; Pu et al., 2002; Miladi Gorji et al., 2008). However, the mechanisms underlying these effects of opiates are poorly understood. 
Adenosine is a neuromodulator that plays an important role in regulating neuronal excitability and basal synaptic transmission in the hippocampus (Dunwiddie and Masino, 2001). It has been shown that adenosine and its analogs inhibit hippocampal LTP predominantly via adenosine $A_{1}$ receptors $\left(A_{1} R s\right.$ ) (Arai et al., 1990; de Mendonça and Ribeiro, 1990; Alzheimer et al., 1991; Forghani and Krnjevic, 1995). Selective $A_{1} R$ agonists and antagonists have been reported to impair and facilitate spatial learning and memory, respectively (Von Lubitz et al., 1993). It has also been shown that there are persistent increases in adenosine tonic inhibition in some brain areas, such as ventral tegmental region (VTA) and nucleus accumbens (NAc), that are intimately involved in the rewarding effects of morphine and cocaine following chronic exposure to the drugs (Bonci and Williams, 1996; Shoji et al., 1999; Fiorillo and Williams, 2000). Based on these findings, we hypothesized that accumulation of extracellular adenosine in the hippocampus might be a possible mechanism underlying the chronic effects of morphine on hippocampal LTP and cognitive function. Therefore, the present study was undertaken to determine whether and how chronic morphine treatment altered hippocampal extracellular adenosine concentrations and whether the altered extracellular adenosine concentrations contributed to the impairment of both hippocampal LTP and spatial memory.

\section{Materials and Methods}

\section{Animals}

Kunming strain male mice ( $18-22 \mathrm{~g}$ ) were obtained from the Laboratory Animal Center, Chinese Academy of Sciences (Shanghai, China) or from the Animal House Center, Kunming Medical University (Kunming, China). Mice were housed in groups and maintained on a $12 \mathrm{~h} \mathrm{light/dark}$ cycle in a temperature-controlled environment with ad libitum access to food and water. All experimental procedures were in compliance with the National Institutes of Health guidelines and were approved by the Local Animal Care and Use Committee.

\section{Animal treatment}

Morphine dependence was induced in mice by using two regimens, increasing doses and equal daily dose. In the increasing dose regimen, mice were subcutaneously injected with morphine twice per day at an interval of $12 \mathrm{~h}$ for 7 consecutive days. The morphine dose was progressively increased as follows: day 1, $20 \mathrm{mg} / \mathrm{kg}$; day 2, $40 \mathrm{mg} / \mathrm{kg}$; day 3, $60 \mathrm{mg} / \mathrm{kg}$; day 4, $80 \mathrm{mg} / \mathrm{kg}$; days 5 and $6,100 \mathrm{mg} / \mathrm{kg}$; day 7, $100 \mathrm{mg} / \mathrm{kg}$ (only one injection in the morning), as described by previous studies (Maldonado et al., 1996; Matthes et al., 1996; Ledent et al., 1999). In the equal daily dose regimen, mice were injected with a lower dose of morphine (20 $\mathrm{mg} / \mathrm{kg}$, s.c.) twice per day at $12 \mathrm{~h}$ intervals for 12 consecutive days, and on day $12,20 \mathrm{mg} / \mathrm{kg}$ was given (only once in the morning). Acute morphine treatment was performed by a single subcutaneous injection of morphine at a dose of $100 \mathrm{mg} / \mathrm{kg}$ on day 7 after repeated subcutaneous injection of saline at an interval of $12 \mathrm{~h}$ for $6 \mathrm{~d}$. One group of mice was treated concomitantly with morphine using the increasing dose regimen and naltrexone ( $4 \mathrm{mg} / \mathrm{kg}$, i.p.) to determine whether $\mu$-opioid receptors were responsible. Naltrexone was injected $30 \mathrm{~min}$ before each morphine injection. Control mice were treated similarly, except that normal saline was used as a substitute for morphine and naltrexone.

Preparation of hippocampal slices and synaptosomes

Mice acutely and chronically treated with morphine in the increasing dose regimen were decapitated $2 \mathrm{~h}$ after the last morphine injection. Mice chronically treated with morphine in the equal daily dose regimen were decapitated at different time points $(2 \mathrm{~h}, 7 \mathrm{~d}, 30 \mathrm{~d})$ after the last morphine injection. Hippocampal slices were prepared as described previously (Zhang et al., 2003). In brief, hippocampus was taken and sectioned into $300 \mu \mathrm{M}$ slices using a vibratome in ice-cold artificial CSF (ACSF) containing the following (in mM): $119 \mathrm{NaCl}, 1.25 \mathrm{NaH}_{2} \mathrm{PO}_{4}, 2 \mathrm{KCl}, 1.3$ $\mathrm{MgCl}_{2}, 2 \mathrm{CaCl}_{2}, 26 \mathrm{NaHCO}_{3}$, and 10 glucose and gassed with $95 \% \mathrm{O}_{2}$ and
$5 \% \mathrm{CO}_{2}$. The slices were maintained in an incubation chamber with artificial ACSF saturated with $95 \% \mathrm{O}_{2}$ and $5 \% \mathrm{CO}_{2}$ for at least $2 \mathrm{~h}$ at room temperature $\left(22-25^{\circ} \mathrm{C}\right)$.

Hippocampal synaptosomes were prepared as described previously (Von Lubitz et al., 1993), with some modifications. In brief, hippocampal tissues from three mice were homogenized on ice by 20 strokes with a tight-fitting Dounce homogenizer in $1 \mathrm{ml}$ of homogenization buffer, $\mathrm{pH}$ 7.4, composed of $0.32 \mathrm{~m}$ sucrose, 5 mM HEPES, pH 7.4, 0.1 mM EDTA, and protease inhibitor mixture (Roche Applied Science), and centrifuged at $1000 \times g$ for $10 \mathrm{~min}$ at $4^{\circ} \mathrm{C}$ to remove cellular debris and nuclei. The supernatant was centrifuged at $12,000 \times g$ for $20 \mathrm{~min}$ at $4^{\circ} \mathrm{C}$ to yield the crude synaptosomal fraction. To remove adhering microsomes, the obtained pellet was washed additional three times by resuspension and recentrifugation at $12,000 \times g$ for $20 \mathrm{~min}$ at $4^{\circ} \mathrm{C}$. The obtained synaptosomes were resuspended in $1 \mathrm{ml}$ of Krebs/HEPES solution with the following composition: $\mathrm{NaCl} 124 \mathrm{~mm}, \mathrm{KCl} 3 \mathrm{~mm}, \mathrm{NaH}_{2} \mathrm{PO}_{4} 1.25 \mathrm{~mm}$, $\mathrm{MgSO}_{4} 1 \mathrm{~mm}, \mathrm{CaCl}_{2} 2 \mathrm{~mm}$, HEPES $26 \mathrm{~mm}$, and glucose $10 \mathrm{~mm}, \mathrm{pH}$ 7.4, and equilibrated at $37^{\circ} \mathrm{C}$ for at least $10 \mathrm{~min}$.

\section{Extracellular adenosine measurements}

For measurement of extracellular adenosine concentration in acute hippocampal slices, three slices were incubated in $400 \mu$ l oxygenized ACSF at $33 \pm 1{ }^{\circ} \mathrm{C}$ for $20 \mathrm{~min}$. When needed, the inhibitor of adenosine transport and antagonist of opioid receptor were added to ACSF (Zhang et al., 2003). The ACSF was then collected and adenosine was assayed by LC/ MS. The LC/MS analysis was performed on a Thermo Finnigan LCQ ion trap mass spectrometer equipped with an atmospheric-pressure ionization interface. The instrument was operated in positive electrospray ionization (ESI) mode. The spray voltage was set at $4.2 \mathrm{kV}$. The capillary temperature was maintained at $450^{\circ} \mathrm{C}$, and the voltage was fixed at $50 \mathrm{~V}$. Quantification was performed by using multitude reaction monitoring $(\mathrm{MRM})$ of the transitions $\mathrm{m} / \mathrm{z} \quad 268 \rightarrow 136$ for adenosine and $\mathrm{m} / \mathrm{z}$ $226 \rightarrow 152$ for acyclovir, with a scan time of $0.2 \mathrm{~ms} /$ transition. The optimized collision energies of $23 \mathrm{eV}$ and $17 \mathrm{eV}$ were chosen for adenosine and acyclovir, respectively. Data were collected and analyzed with Xcalibur software (version 1.2, Thermo Finnigan). Liquid chromatography was performed with a Shimadzu LC-10AD solvent delivery system. The samples were separated on a Zobax XDB-C18 column $(150 \mathrm{~mm} \times 4.6$ $\mathrm{mm}$ inner diameter, $5 \mu \mathrm{m}$, Agilent). The mobile phase consisted of methanol-water-formic acid (40:60:0.3, v:v:v) at a flow rate of $0.5 \mathrm{ml} / \mathrm{min}$.

\section{Evaluation of cellular integrity}

Cellular integrity of the slices was evaluated as previously described (Cunha et al., 2000). In brief, the slices were allowed to recover for $2 \mathrm{~h}$ and were incubated for $20 \mathrm{~min}$ with $400 \mu$ l oxygenated ACSF solution at $33 \pm$ $1{ }^{\circ} \mathrm{C}$. Cellular disruption was determined by comparing the lactate dehydrogenase activity in the incubation medium with that found in the slices on their solubilization with $2 \%(\mathrm{v} / \mathrm{v})$ Triton X-100. The release of lactate dehydrogenase was only $2-4 \%$ of the total lactate dehydrogenase, which indicates low levels of cellular disruption during the experiments.

\section{$\left[{ }^{3} \mathrm{H}\right]$ Adenosine uptake assay}

All adenosine transport assays were conducted at $37^{\circ} \mathrm{C}$ in a total volume of $300 \mu \mathrm{l}$, containing $150-200 \mu \mathrm{g}$ of protein. Transport was initiated by addition of $1 \mu \mathrm{M}\left[{ }^{3} \mathrm{H}\right]$ adenosine, added at least $10 \mathrm{~min}$ after exposing synaptosomes to the tested drugs, and was terminated $15 \mathrm{~s}$ after initiating its uptake by the addition of $5 \mathrm{ml}$ of an ice-cold transport inhibitor mixture composed of dipyridamole $(20 \mu \mathrm{M})$, nitrobenzylthioinosine (NBTI) $(10 \mu \mathrm{M})$, and adenosine $(1 \mathrm{~mm})$, in Krebs/HEPES followed by low-pressure filtration through GF/C filters (Millipore LCWP-047, Millipore Corporation) loaded in a Millipore holder. The reaction tube was washed off with further $5 \mathrm{ml}$ of the same solution. The filters were analyzed by liquid scintillation counting for determination of tritium retained by synaptosomes after addition of $5 \mathrm{ml}$ of scintillation cocktail. To avoid the loss of adenosine transport activity, the hippocampal synaptosomes were prepared freshly for every test. Membrane protein concentrations were determined by a Bradford assay (Pinto-Duarte et al., 2005).

\section{Adenosine metabolism enzyme activity assay}

The samples were prepared as previously described with slight modifications (Delaney et al., 1997). In short, the hippocampus were homoge- 
nized in $1 \mathrm{ml}$ of homogenization buffer, $\mathrm{pH} 7.4$, composed of $0.32 \mathrm{M}$ sucrose, 5 mM HEPES, pH 7.4, $0.1 \mathrm{~mm}$ EDTA, and protease inhibitor mixture (Roche Applied Science), and centrifuged at $1000 \times g$ for $10 \mathrm{~min}$ at $4^{\circ} \mathrm{C}$ to remove cellular debris and nuclei. The supernatant was centrifuged at $100,000 \times g$ for $60 \mathrm{~min}$ at $4^{\circ} \mathrm{C}$. The supernatant was used in assays for adenosine kinase and adenosine deaminase activities. The pellet was resuspended in $1 \mathrm{ml}$ of homogenization buffer used for the ecto5 '-nucleotidase assay. The activity of adenosine kinase was analyzed radiochemically from tissue extracts by monitoring the conversion of $\left[{ }^{3} \mathrm{H}\right]$ adenosine into $\left[{ }^{3} \mathrm{H}\right] \mathrm{AMP}$ with a method previously described (Ward et al., 1998). Adenosine deaminase and ecto- $5^{\prime}$-nucleotidase activity were assayed by using a spectrophotometric method to detect formation of ammonia and inorganic phosphate as described previously.

\section{Protein kinase $C$ activity assay}

PKC activity was determined essentially according to the method described previously (Xu et al., 2004). The animal was rapidly decapitated, the hippocampus was dissected rapidly, and the hippocampal synaptosomal fraction was isolated as described above. The synaptosomes were assayed for PKC activity using PepTag Nonradioactive PKC assay kit (Promega) according to the manufacturer's instructions. All reaction components were added on ice in a final volume of $25 \mu \mathrm{l}$ of the following mixture: $5 \mu \mathrm{l}$ of PepTag PKC reaction $5 \times$ buffer, $5 \mu \mathrm{l}$ of PepTag C1 peptide $(0.4 \mu \mathrm{g} / \mu \mathrm{l}), 5 \mu \mathrm{l}$ of PKC activator $5 \times$ solution, $1 \mu \mathrm{l}$ of peptide protection solution, and $1 \mu \mathrm{g}$ of synaptosome for PKC activity assay. The mixture was incubated for $10 \mathrm{~min}$ at $37^{\circ} \mathrm{C}$. The reaction was stopped by placing the tube into a boiling water bath for $10 \mathrm{~min}$, and the samples were loaded onto the gel for electrophoresis. Before loading samples, $1 \mu \mathrm{l}$ of $80 \%$ glycerol was added to the sample to ensure that it remained in the well. The assay was based on the changes in the net charge of the fluorescent PKC substrates before and after phosphorylation. This change allowed the phosphorylated and unphosphorylated versions of the substrate to be rapidly separated on an agarose gel at neutral $\mathrm{pH}$. The phosphorylated species migrated toward the positive electrode, whereas the nonphosphorylated substrate migrated toward the negative electrode. The intensity of fluorescence of phosphorylated peptides, which reflected the activity of $\mathrm{PKC}$, was scanned by using a bioimaging system and further quantified by using Scion Image for Windows (Scion).

\section{Immunoblotting assay}

For immunoblotting assay, the crude synaptosomes were prepared as described above and then were homogenized on ice in homogenization buffer containing $25 \mathrm{~mm}$ Tris-HCl, pH 7.4, 0.5 mm EDTA, 0.5 mм EGTA, $0.5 \%$ Triton X-100, and protease inhibitor mixture. Homogenates were then centrifuged at $20,000 \times g$ for $40 \mathrm{~min}$ at $4^{\circ} \mathrm{C}$. After given a protein concentration of $0.5 \mathrm{mg} / \mathrm{ml}$ that was determined by Bradford methods, four times loading buffer was added to each supernatant before boiling for $5 \mathrm{~min}$. Samples were cooled and subjected to SDS-PAGE (10 $\mu \mathrm{g}$ for PKC- $\alpha / \beta$ and PKC $-\gamma, 30 \mu \mathrm{g}$ for ENT1/2 and PKC- $\varepsilon, 12 \%$ resolving gels) and transferred onto nitrocellulose membrane (GE Healthcare). Membranes were washed with TBST (Tris-buffered saline plus $0.05 \%$ Tween $20, \mathrm{pH} 7.4$ ) and then dipped in blocking buffer (5\% skimmed dry milk in TBST) $1 \mathrm{~h}$ at room temperature. After slightly washing, the membrane was incubated with anti-ENT1 goat polyclonal antibody (1:50 Santa Cruz Biotechnology, sc-48488), anti-ENT2 goat polyclonal antibody (1:50, Santa Cruz Biotechnology sc-48491), anti-PKC- $\alpha / \beta$ monoclonal antibody, anti-PKC- $\gamma$ rabbit polyclonal antibody $(1: 10,000$, Santa Cruz Biotechnology sc-211), anti-PKC- $\varepsilon$ mouse monoclonal antibody (1:50, Santa Cruz Biotechnology sc-56944) in TBS plus 5\% BSA and $0.1 \%$ Tween 20 , followed by incubation with horseradish peroxidaseconjugated IgG (Calbiochem) as the secondary antibody. Visualization was performed using an ECL (enhanced chemiluminescence) kit (GE Healthcare) for PKC- $\alpha / \beta$ (Busquets et al., 1995) and PKC- $\gamma$, SuperSignal West Dura Extended Duration Substrate (Thermo Scientific) for ENT1/2 and $\mathrm{PKC}-\varepsilon$. Band intensities were quantified by using Quantity One software from Bio-Rad.

\section{Electrophysiological recordings}

Extracellular recordings on brain slices were performed as described in our previous study (H. B. Li et al., 2008). Briefly, the hippocampal slices, obtained as described above, were incubated for $1 \mathrm{~h}$ in $300 \mathrm{ml}$ of ACSF heated to $33 \pm 1{ }^{\circ} \mathrm{C}$ and then maintained at room temperature (22$25^{\circ} \mathrm{C}$ ). Slices were placed in a recording chamber and perfused by ACSF with a flow rate of $4-5 \mathrm{ml} / \mathrm{min}$. A glass recording electrode filled with ACSF (2-3 M $\Omega$ ) was placed in the stratum radiatum of the CA1 region. The field EPSPs (fEPSPs) were evoked by stimulation of the Schaffer collaterals. Electrical stimuli were delivered at a frequency of $0.033 \mathrm{~Hz}$ to record baseline fEPSP and at a stimulation intensity adjusted to give an fEPSP amplitude of $50 \%$ maximum response. In all experiments, baseline synaptic transmission was monitored for $30 \mathrm{~min}$ before drug administration or delivering the stimulation. LTP was induced by high-frequency stimulation (HFS, 100 pulses at $200 \mathrm{~Hz}, 3$ trains, $30 \mathrm{~s}$ intertrain intervals), and the same stimulation intensity was used for baseline recordings.

\section{Behavioral experiments}

Spontaneous or naloxone-precipitated opiate withdrawal monitoring. We tested somatic withdrawal signs in different groups of mice $(n=10-12$ per group) that were injected with saline or morphine with the increasing dose regimen $(20-100 \mathrm{mg} / \mathrm{kg}$, s.c., twice per day) or equal daily dose regimen $(20 \mathrm{mg} / \mathrm{kg}$, s.c., per day) and examined for somatic withdrawal signs $2,8,12,24$, and $36 \mathrm{~h}$ and $7 \mathrm{~d}$ after the last morphine administration. The experimental design included the between-subjects factors of morphine treatment and withdrawal time points $(2,8,12,24$, and $36 \mathrm{~h}$ and 7 d). Spontaneous withdrawal syndrome tests were performed as described by previous study (Papaleo and Contarino, 2006). Briefly, mice that were treated with morphine using the increasing dose or equal daily dose regimen as mentioned above were individually placed in transparent Plexiglas cylinders ( $23 \mathrm{~cm}$ diameter, $50 \mathrm{~cm}$ height) for $30 \mathrm{~min}$. Withdrawal signs (e.g., jumping, paw tremor, wet dog shake, body weight lost, diarrhea, and palpebral ptosis) were monitored at different time points $(2,8,12,24$, and $36 \mathrm{~h}$ and $7 \mathrm{~d})$ after the last morphine administration and global withdrawal scores were calculated. Naloxone-precipitated morphine withdrawal tests were performed as described by our previous study (Chen et al., 2007). Briefly, mice were chronically treated with morphine for $7 \mathrm{~d}$ (increasing dose regimen) or $12 \mathrm{~d}$ (equal daily dose regimen), withdrawal was precipitated by subcutaneous injection of naloxone $(2 \mathrm{mg} / \mathrm{kg}) 2 \mathrm{~h}$ after the last morphine administration, and then the mice were individually placed in transparent Plexiglas cylinders. The jumping frequency of each mouse and the number of mice that jumped in each group within 20 min were recorded. The positive jumping response was defined as jumping more than four times in $20 \mathrm{~min}$.

Morris water maze. The Morris water maze was performed as described previously (Morris et al., 1986; Miladi Gorji et al., 2008) with slight modification. Briefly, the Morris water maze consisted of a circular pool ( $100 \mathrm{~cm}$ diameter, $36 \mathrm{~cm}$ deep at the side) filled with water at $25 \pm 1^{\circ} \mathrm{C}$ to a depth of $13 \mathrm{~cm}$, covering the surface with floating black resin beads. Yellow curtains were drawn around the pool $(50 \mathrm{~cm}$ from the pool periphery) and contained distinctive visual marks that served as distal cues. Mice were chronically treated with morphine for 6 or $12 \mathrm{~d}$ as described above, trained, and tested in Morris water maze for the next $7 \mathrm{~d}$, during which $100 \mathrm{mg} / \mathrm{kg}$ or $20 \mathrm{mg} / \mathrm{kg}$ morphine was still injected at $12 \mathrm{~h}$ intervals to maintain the chronic drug treatment. All the behavioral trainings and tests were performed $2 \mathrm{~h}$ after the morning injection of morphine or saline each day. On day 1, a $60 \mathrm{~s}$ free swimming trial was performed for adaptation. On days $2-6$, the training procedure was given containing four trials per day with four different starting positions that were equally distributed around the perimeter of the maze. A submerged $(1.5 \mathrm{~cm}$ below the surface of the water, invisible to the animal) Perspex platform $(10 \mathrm{~cm} \times 10 \mathrm{~cm})$ was placed in the center of a quadrant fixedly to let the animals learn the location of the platform that could be used to escape from the water. Two hours after the last morphine or saline injection on day 7 , a probe trial consisting of a $60 \mathrm{~s}$ free swim period without the platform was performed to test spatial memory. DMSO or 8-cyclopentyl1,3-dipropylxanthine (DPCPX) $\left(0.1 \mathrm{mg} \cdot \mathrm{kg}^{-1}\right.$, i.p. $)$ was injected $30 \mathrm{~min}$ before the probe trial ( $1.5 \mathrm{~h}$ after the last injection of morphine or saline). In the constant-dose regimen, behavioral training and test were similar with those in the progressive-doses regimen, except that the training started on day 6 and the probe trial performed on day 13, $2 \mathrm{~h}$ after an additional mor- 
A

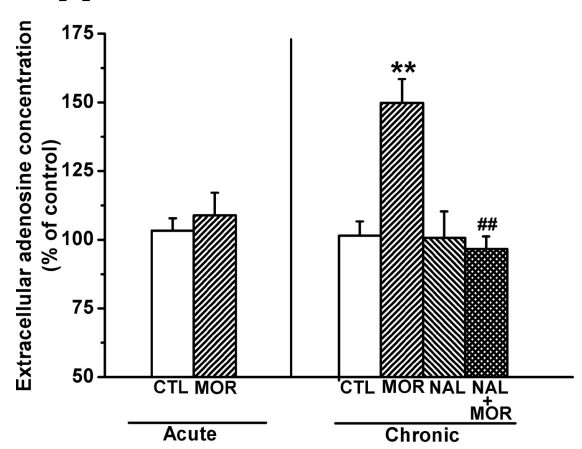

B
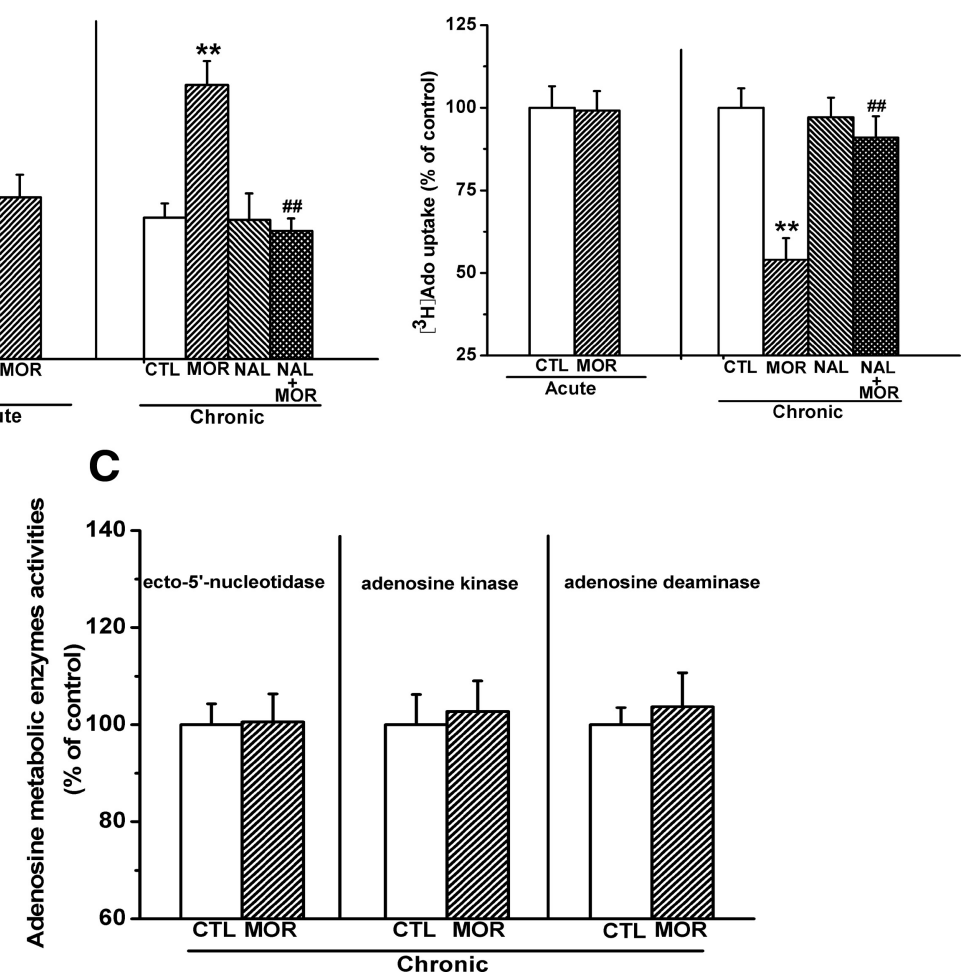

Figure 1. Effects of chronic treatment of mice with increasing doses of morphine $(20-100 \mathrm{mg} / \mathrm{kg})$ for 7 consecutive days on adenosine uptake, extracellular adenosine accumulation, and three adenosine metabolism enzyme activities. $\boldsymbol{A}$, Chronic morphine treatment significantly increased the extracellular adenosine concentrations in hippocampal slices, and this effect could be prevented by concomitant injection of opioid receptor antagonist naltrexone (4 mg/kg, i.p.). $\boldsymbol{B}$, Chronic morphine treatment significantly inhibited $\left[{ }^{3} \mathrm{H}\right]$ adenosine uptake in hippocampal synaptosomes, and this effect could also be prevented by opioid receptor antagonist naltrexone. $\boldsymbol{C}$, Chronic morphine treatment had no significant effect on the activities of three crucial adenosine metabolism enzymes in the hippocampus. Data represent the mean $\pm \operatorname{SEM}(n=4) .{ }^{* *} p<0.01$ compared with saline-treated control mice; ${ }^{\# \#} p<0.01$ compared with mice treated with morphine alone $(n=8)$, two-way ANOVA test. CTL, Control; MOR, morphine; NAL, naltrexone.

phine $(20 \mathrm{mg} / \mathrm{kg})$ or saline injection. Swimming paths for the training session and probe trial were monitored using an automatic tracking system. This computerized tracking system was used to record the escape latency (latency to find the platform), swimming trace, initial crossing latency to the platform location, number of platform location crossings, time spent in target quadrant, and distance traveled to reach the platform in four different quadrants for each trial (Moser et al., 1998; Yang et al., 2006).

\section{Statistical analysis}

Data are expressed as mean \pm SEM and analyzed with one- or two-way ANOVA or Student's $t$ tests (see Results). The appropriate between- and within-subjects factors for the different experiments were used for twoway ANOVAs (see Results). Significant main effects and interactions $(p<$ 0.05) from the factorial ANOVAs were followed by post hoc protected least significant difference (PLSD) tests. Because the multiple factorial ANOVAs yield multiple main effects and interaction effects, only significant effects that are critical for the interpretation of the data in Results were reported. Additionally, for clarity purposes, post hoc analyses are indicated by asterisks in the figures but are not described in Results (Y. Q. Li et al., 2008).

\section{Results}

Chronic morphine treatment induced hippocampal extracellular adenosine accumulation by decreasing adenosine reuptake

We assessed extracellular adenosine concentrations in the hippocampal slices from mice that were acutely or chronically injected with morphine. The average basal extracellular adenosine concentration was $20.2 \pm 0.8 \mathrm{~nm} / \mathrm{mg}$ of tissue $(n=15)$ in the hippocampal slices from saline-treated mice. As shown in Fig- ure $1 A$, acute treatment with morphine (100 $\mathrm{mg} / \mathrm{kg}$, s.c.) following chronic treatment with saline for $6 \mathrm{~d}$ had no effect on hippocampal extracellular adenosine concentration (left). However, chronic morphine treatment with the increasing dose regimen $(20-100 \mathrm{mg} / \mathrm{kg}$, s.c.) for $7 \mathrm{~d}$ led to an increase in the extracellular adenosine concentrations, and this effect could be prevented by concomitant administration of opioid receptor antagonist naltrexone ( $4 \mathrm{mg} / \mathrm{kg}$, i.p.) before each morphine injection (right). Two-way ANOVA with the between-subjects factors of morphine treatment and naltrexone treatment revealed a significant effect of morphine $\left(F_{(1,27)}=10.475, p<0.01\right)$ and a significant interaction between the two factors $\left(F_{(1,27)}=14.61, p<0.01\right)$. Post hoc group differences are indicated in Figure $1 \mathrm{~A}$ (right).

Extracellular adenosine concentration can be modulated either by changing adenosine metabolism enzyme (e.g., adenosine kinase, ecto-5' ${ }^{\prime}$-nucleotidase, and adenosine deaminase) activity or by regulating reuptake function of bidirectional equilibrative adenosine transporters (ENTs) (Dunwiddie and Masino, 2001). To determine the mechanisms of extracellular adenosine accumulation, we examined the activities of these three key adenosine metabolism enzymes and the uptake of $\left[{ }^{3} \mathrm{H}\right]$ adenosine in the hippocampal tissues from chronic morphine-treated mice $2 \mathrm{~h}$ after the last morphine injection. In saline-treated animals, the average uptake of $\left[{ }^{3} \mathrm{H}\right]$ adenosine by hippocampal synaptosomes was $1.1 \pm 0.1$ $\mathrm{pmol} / \mathrm{mg}$ of protein $/ 15 \mathrm{~s}(n=10)$, and there was no difference in $\left[{ }^{3} \mathrm{H}\right]$ adenosine uptake between hippocampal synaptosomes from acute morphine- and saline-treated mice (Fig. $1 B$, left). However, chronic morphine treatment resulted in a reduction of the uptake of $\left[{ }^{3} \mathrm{H}\right]$ adenosine $(54.01 \pm 6.52 \%$ of control), and this effect was reversed by concomitant administration of naltrexone ( $4 \mathrm{mg} / \mathrm{kg}$, i.p.) before each morphine injection (Fig. $1 B$, right). Two-way ANOVA with the between-subjects factors of morphine treatment and naltrexone treatment revealed a significant effect of morphine treatment $\left(F_{(1,28)}=20.36, p<0.01\right)$ and a significant interaction between these two factors $\left(F_{(1,28)}=8.28, p<0.01\right)$. In contrast, chronic morphine treatment had no significant effect on the activity of three adenosine metabolism enzymes (Fig. 1C). Together, these results indicate that chronic morphine treatment increases extracellular adenosine concentrations by attenuating adenosine uptake but not by altering adenosine metabolisms.

Increased hippocampal extracellular adenosine accumulation was not correlated with morphine withdrawal

Withdrawal from chronic opiate treatment may lead to the elevation of extracellular adenosine concentrations via intracellular cAMP accumulation in some brain regions, such as VTA, NAc, and the periaqueductal gray area (Bonci and Williams, 1996; Chieng and Williams, 1998; Ingram et al., 1998; Shoji et al., 1999; Hack et al., 2003). To determine whether adenosine accumula- 
tion at $2 \mathrm{~h}$ after last morphine administration is correlative to morphine withdrawal, we examined morphine withdrawal symptoms at different time points after last morphine administration and analyzed the jumps and global scores using repeatedmeasures ANOVA with morphine treatment as a between-subjects factor and time point after last morphine administration as a within-subject factor. As shown in Figure 2, $A$ and $B$, mice chronically treated with morphine using the increasing dose regimen did not spontaneously express withdrawal signs before $24 \mathrm{~h}$ (evaluated by jumps) and $2 \mathrm{~h}$ (evaluated by global scores), or after $36 \mathrm{~h}$ (evaluated by both) after last morphine administration. But, analysis of jumps occurring 24 and $36 \mathrm{~h}$ after the last morphine injection revealed a significant interaction between morphine treatment and time $\left(F_{(5,90)}=3.63, p<0.01\right)$, and analysis of global scores at $8,12,24$, and $36 \mathrm{~h}$ after last morphine administration revealed a significant interaction between morphine treatment and time $\left(F_{(5,90)}=3.774, p<\right.$ $0.01)$. Post hoc group differences are indicated in Figure 2, $A$ and $B$.

To further confirm that observed hippocampal extracellular adenosine accumulation did not result from morphine withdrawal, we measured adenosine concentrations in the same hippocampal slices in the presence or absence of morphine $(10 \mu \mathrm{M})$ in incubating ACSF. There was no significant difference in adenosine concentrations between the hippocampal slices incubated with or without morphine (Fig. 2C). However, precipitation of the hippocampal slices with naloxone $(1 \mu \mathrm{M})$ caused a robust enhancement of adenosine accumulation $\left(t_{(10)}=3.64 ; p<0.01\right.$, Student's $t$ test) (Fig. $2 D$ ). The results indicate that the hippocampal slices prepared from chronic morphine-treated mice $2 \mathrm{~h}$ after the last morphine administration were in a dependent but not withdrawal state, consistent with the findings from in vivo studies. These results indicate that adenosine accumulation in the hippocampal slices is not correlated with morphine withdrawal reactions.

\section{Chronic morphine treatment impaired the function of equilibrative nucleoside transporters}

Extracellular adenosine levels are regulated by ENT. In the CNS, ENT appears to be dominant (Thorn and Jarvis, 1996) and plays a predominant role in controlling the levels of extracellular adenosine (Latini and Pedata, 2001). ENT can be classified into ENT1 and ENT2 based on sensitivity to the selective inhibitor NBTI. ENT1 is an NBTI-sensitive transporter that is inhibited by NBTI at low nanomolar concentrations, whereas ENT2 is an NBTIinsensitive transporter that is inhibited by NBTI at micromolar concentrations. To determine whether reduction of $\left[{ }^{3} \mathrm{H}\right]$ adenosine uptake is attributable to the impairment of ENT1/2 function, we compared the effect of various concentrations of NBTI on extracellular adenosine accumulation in hippocampal slices prepared from saline- and chronic morphine-treated mice.

\section{B}
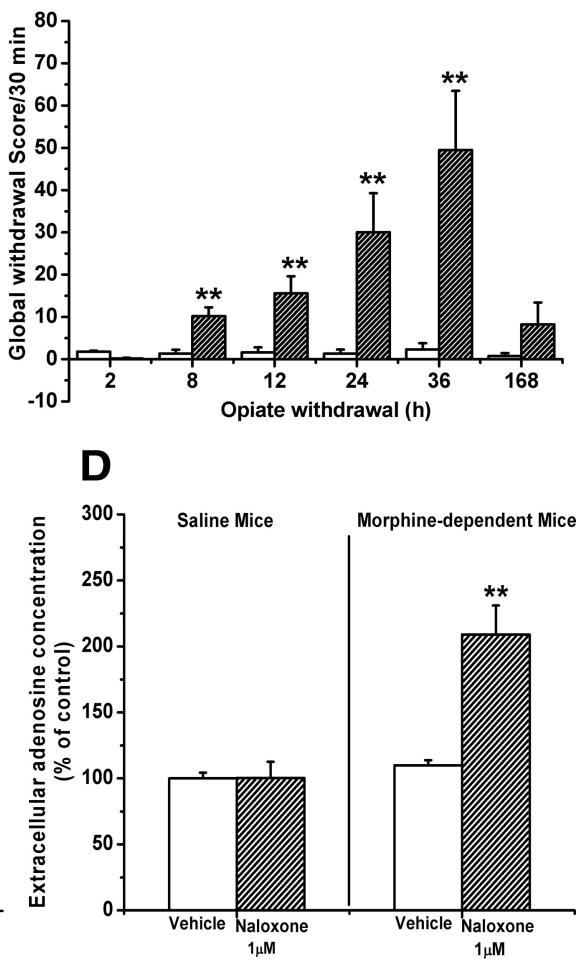

Figure 2. Spontaneous morphine withdrawal signs were not observed in chronic morphine-treated mice and the hippocampal

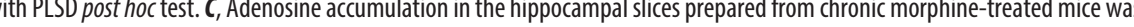
作 05 compared with saline-treated control mice, one-way ANOVA with PLSD post hoc test. $\boldsymbol{D}$, Naloxone precipitation ( $1 \mu \mathrm{M})$ 政

As shown in Figure $3 A$, NBTI failed to affect hippocampal extracellular adenosine concentrations in both chronic salineand morphine-treated mice at nanomolar concentrations. However, one-way ANOVA analysis revealed that at the dose of $10 \mu \mathrm{M}$, NBTI significantly increased extracellular adenosine concentrations in the hippocampal slices from both chronic morphine- $\left(F_{(3,17)}=4.00, p<0.05\right.$, one-way ANOVA $)$ and saline- $\left(F_{(3,19)}=10.67, p<0.01\right.$, one-way ANOVA $)$ treated mice. Treatment with $10 \mu \mathrm{M}$ NBTI led to an elevation of extracellular adenosine concentrations by $63.55 \%$ in the hippocampal slices from saline-treated mice (Fig. $3 A$, left). However, treatment with $10 \mu \mathrm{M}$ NBTI led to elevation of extracellular adenosine concentrations by only $28.97 \%$ in the hippocampal slices from chronic morphine-treated mice (Fig. $3 A$, right), significantly less than that in the hippocampal slices from chronic saline-treated mice $\left(t_{(9)}=3.6, p<0.01\right.$, Student's $t$ test $)$, indicating that the ability of ENT2 to uptake extracellular adenosine in the hippocampus from morphine-treated mice was decreased and suggesting that chronic morphine treatment attenuated ENT2 function.

Next, we examined the effect of chronic morphine treatment on ENT2 expression. We found that chronic morphine treatment led to a slight elevation of ENT1 but reduction of ENT2 expression in the hippocampus prepared from chronic morphine-treated mice. However, paired Student's $t$ test analysis showed that neither elevation of ENT1 expression nor reduction 

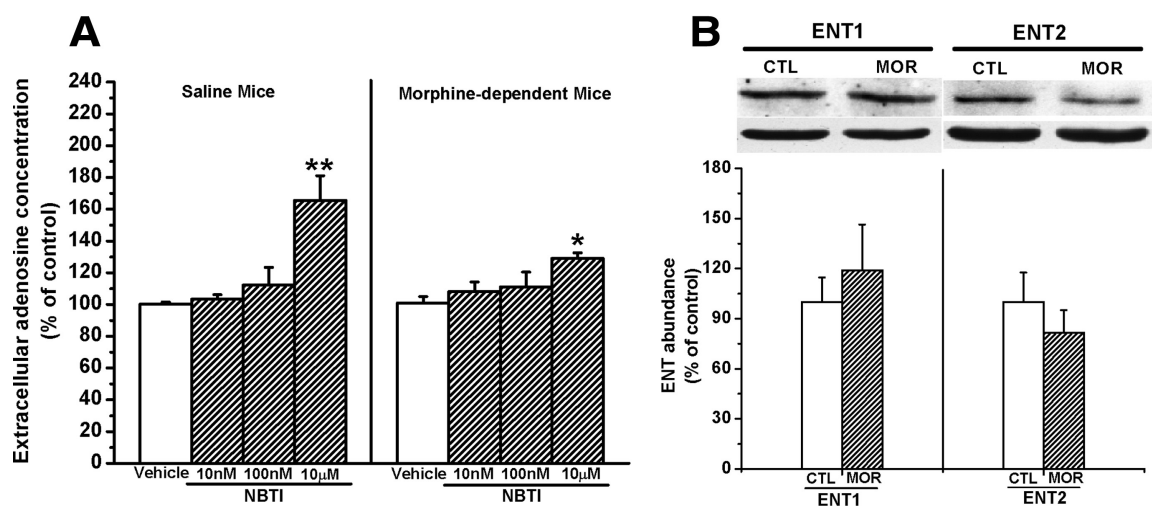

Figure 3. Chronic morphine treatment attenuated the activity but did not decrease the expression of ENT2.A, Effect of different concentrations of NBTI, a selective inhibitor of ENTs, on the uptake of adenosine in the hippocampal synaptosomes prepared from saline- and chronic morphine-treated mice. Data are presented as the percentage of control and represent the mean \pm SEM $(n=$ 6). ${ }^{* *} p<0.01$ compared with vehicle group from saline-treated mice. ${ }^{*} p<0.05$ compared with vehicle group from morphinetreated mice, one-way ANOVA with PLSD post hoc test. $\boldsymbol{B}$, There is no significant alteration of expression of ENT1 and ENT2 in the hippocampus from chronic morphine mice. Data are represented as mean $\pm \operatorname{SEM}(n=5)$.

of ENT2 expression reached statistical significance (for ENT1, $t_{(10)}=-0.610, p>0.05$; for ENT2, $\left.t_{(6)}=0.826, p>0.05\right)$ (Fig. $3 B)$, suggesting that decrement of activity rather than alteration of expression mainly contributed to the attenuation of ENT2 function. We also found that acute morphine treatment had no effect on ENT1 and ENT 2 expressions (data not shown).

Attenuation of PKC activity was correlated with the impairment of equilibrative nucleoside transporter function in the hippocampal synaptosomes from chronic morphine-treated mice

ENTs have been reported to be modulated by PKC (Huang et al., 2003; Pinto-Duarte et al., 2005). We thus hypothesized that chronic morphine treatment might attenuate PKC activity, which may contribute to impairment of ENT2 function, thereby leading to the enhancement of extracellular adenosine concentrations. To test this hypothesis, we first examined the effects of selective PKC antagonist chelerythrine and agonist phorbol 12,13-didecanoate (PDD) on the uptake of $\left[{ }^{3} \mathrm{H}\right]$ adenosine. As shown in Figure $4 A$, treatment of hippocampal synaptosomes prepared from untreated mice with $5 \mu \mathrm{M}$ chelerythrine resulted in a significant reduction of the uptake of $\left[{ }^{3} \mathrm{H}\right]$ adenosine, whereas treatment with PDD (500 nM) led to a significant enhancement of the uptake of $\left[{ }^{3} \mathrm{H}\right.$ ] adenosine (chelerythrine: $53.3 \pm 11.28 \%$ of control, PDD: $137.91 \pm 7.84 \%$ of control, $F_{(2,9)}=24.36, p<0.01$, one-way ANOVA) (left). The same effects of chelerythrine ( $4 \mu$ g, i.c.v.) and PDD (300 ng, i.c.v.) on adenosine uptake were also observed in vivo studies (chelerythrine: $66.6 \pm 10.8 \%$ of control, PDD: $174.55 \pm 23.1 \%$ of control, $F_{(2,15)}=7.41, p<0.01$, one-way ANOVA) (right). These results indicate that PKC plays a role in modulation of ENT function. Next, we determined whether chronic morphine treatment attenuated PKC activity. As shown in Figure 4B, consistent with a previous study (Xu et al., 2004), chronic treatment with morphine attenuated PKC activity in the hippocampal synaptosomes derived from chronic morphinetreated mice (right). Two-way ANOVA with the betweensubjects factors of morphine treatment and naltrexone treatment revealed a significant effect of morphine treatment $\left(F_{(1,12)}=\right.$ 10.81, $p<0.01)$ and a significant interaction between the two factors $\left(F_{(1,12)}=11.09, p<0.01\right)$. However, the attenuation of PKC activity was not observed in the hippocampal synaptosomes from acute morphine-treated mice (left). To verify the role of attenuation of $\mathrm{PKC}$ activity in the impairment of ENT2 function, we further examined the correlation of the attenuation of PKC activity with reduction of $\left[{ }^{3} \mathrm{H}\right]$ adenosine uptake and enhancement of extracellular adenosine concentration. To this end, we detected attenuation of PKC activity, reduction of $\left[{ }^{3} \mathrm{H}\right]$ adenosine uptake, and increment of extracellular adenosine accumulation at different time points $(1,2$, and $12 \mathrm{~h})$ after the last morphine administration (Fig. $4 C-E$ ). Oneway ANOVA within the time points $(1,2$, and $12 \mathrm{~h}$ ) after last morphine administration revealed significant effects of chronic morphine treatment on PKC activity $\left(F_{(3,18)}=8.29, p<0.01\right),\left[{ }^{3} \mathrm{H}\right]$ adenosine uptake $\left(F_{(3,20)}=9.64, p<0.01\right)$, and adenosine concentrations $\left(F_{(3,22)}=22.30\right.$, $p<0.01)$ at 1 and $2 \mathrm{~h}$, respectively, but not at $12 \mathrm{~h}(p>0.05)$. Together, these results show that at observed time points $(1,2$, and $12 \mathrm{~h})$, changes in PKC activity in the hippocampal synaptosomes were correlated with alterations of the uptake of $\left[{ }^{3} \mathrm{H}\right]$ adenosine and extracellular adenosine concentrations, suggesting that attenuation of PKC activity may be responsible for the impairment of ENT2 function.

Chronic morphine treatment caused downregulation of PKC$\boldsymbol{\alpha} / \boldsymbol{\beta}$ but not PKC- $\boldsymbol{\gamma} / \boldsymbol{\varepsilon}$ expression in the hippocampus

Although it is known that there are several discrete subspecies of PKC (Nishizuka, 1988), the activities of PKC- $\alpha / \beta$ isoforms are the greatest in the mammalian brain (Huang et al., 1986; Jaken and Kiley, 1987; Nishizuka, 1988). To elucidate the mechanism underlying the attenuation of PKC activities in the hippocampus by chronic morphine treatment, we thus investigated the effect of chronic morphine treatment on $\mathrm{PKC}-\alpha / \beta$ expression. As shown in Figure $5 A$, chronic morphine treatment decreased the abundance of $\mathrm{PKC}-\alpha / \beta$ in the hippocampal synaptosomes prepared from mice $2 \mathrm{~h}$ after the last morphine administration, and this reduction of PKC- $\alpha / \beta$ expression was prevented by concomitantly injecting naltrexone $(4 \mathrm{mg} / \mathrm{kg}$, i.p.) before each morphine administration. Two-way ANOVA with the between-subjects factors of morphine treatment and naltrexone treatment revealed a significant effect of morphine treatment $\left(F_{(1,18)}=\right.$ $4.76, p<0.05)$ and a significant interaction between the two factors $\left(F_{(1,18)}=56.46, p<0.01\right)$. However, changes in the PKC$\alpha / \beta$ expression were not observed in the hippocampal synaptosomes from acute morphine-treated mice (left). Consistent with the recovery of PKC activity at $12 \mathrm{~h}$ after the last morphine administration (Fig. 4C), the recovery of abundance of PKC- $\alpha / \beta$ was also observed at $12 \mathrm{~h}$ after the last injection of morphine (Fig. $5 B$ ), suggesting a causal relation between the downregulation of PKC- $\alpha / \beta$ expression and decrement of PKC activity. The correlation of reduction of $\mathrm{PKC}-\alpha / \beta$ expression with decrease in $\mathrm{PKC}$ activity was also supported by the observations that naltrexone inhibited chronic morphine-induced both reduction of $\mathrm{PKC}$ $\alpha / \beta$ expression (Fig. 5A) and decrease in PKC activity (Fig. 4B).

Since PKC- $\gamma / \varepsilon$ has been reported to be implicated in morphine tolerance and reinforcing effects (Narita et al., 2001; Newton et al., 2007; Smith et al., 2007), we next examined the effect of chronic morphine treatment on PKC- $\gamma / \varepsilon$ expression. As shown in Figure 5, $C$ and $D$, both acute and chronic morphine treatment did not significantly alter PKC $-\gamma / \varepsilon$ expression. 


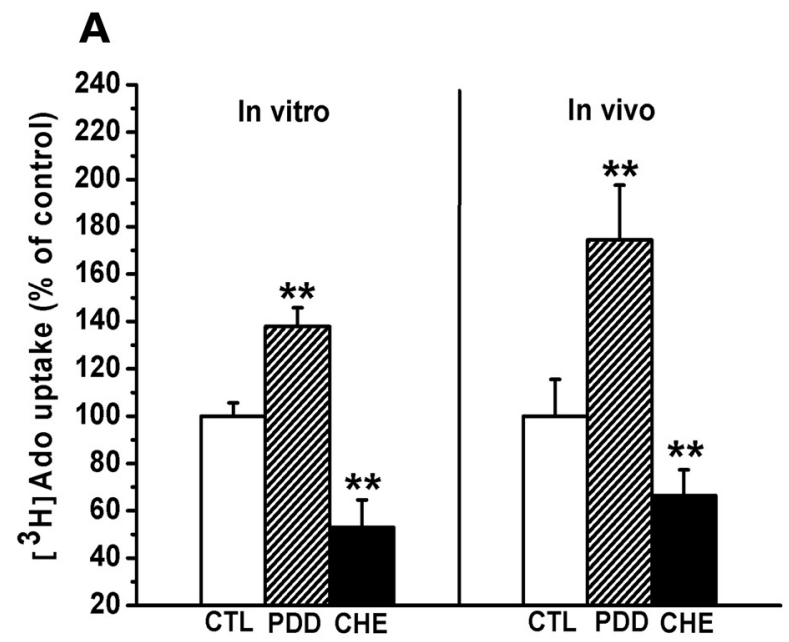

C

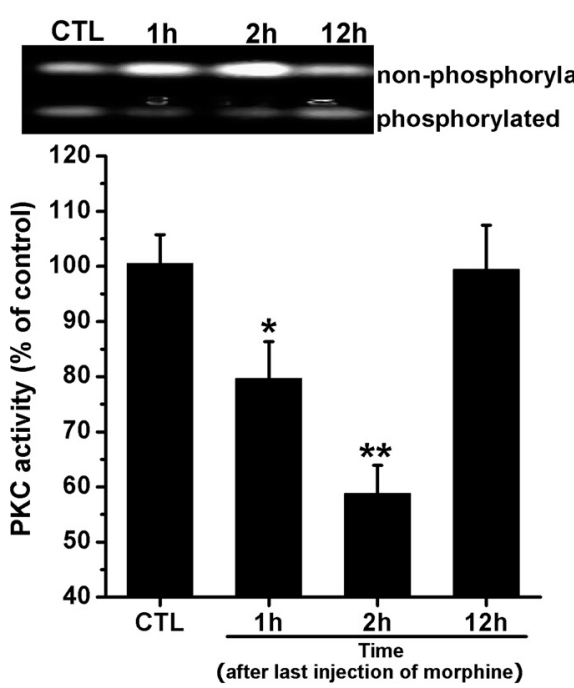

D

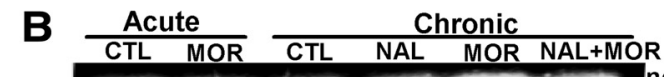
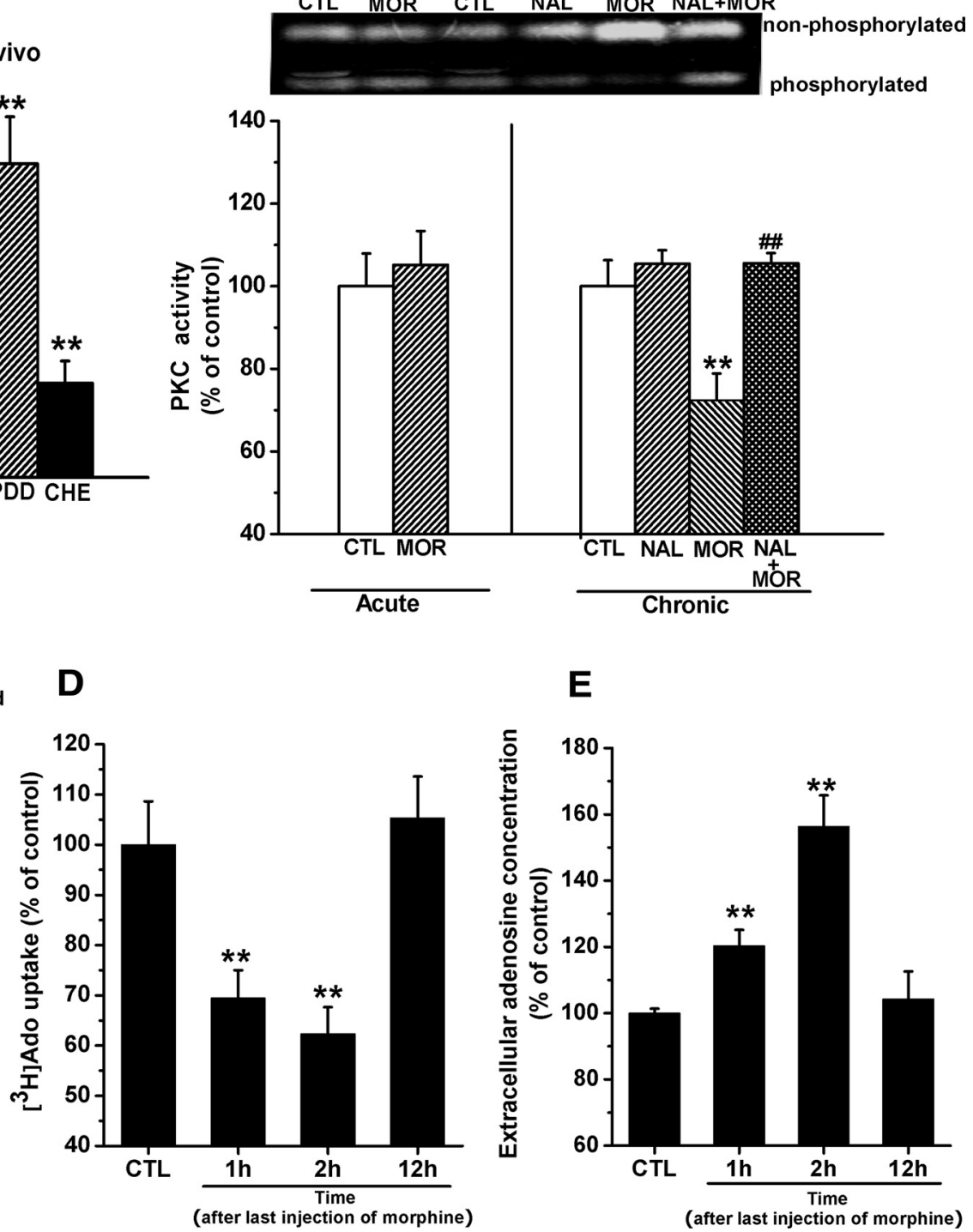

E

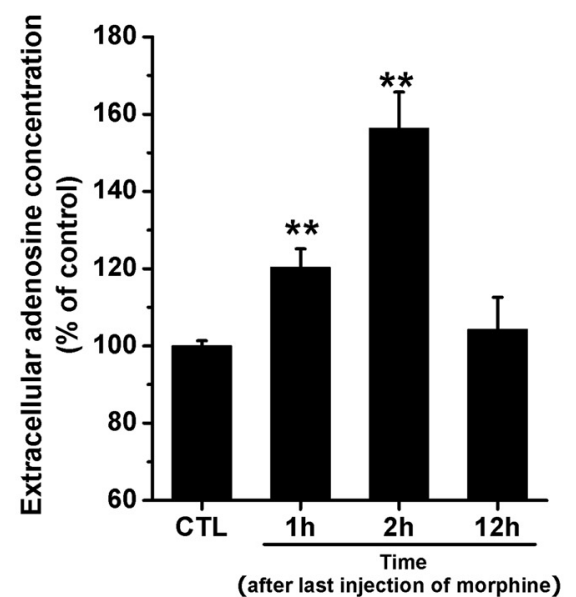

Figure 4. Attenuation of PKC activity was correlated with the impairment of equilibrative nucleoside transporter function in the hippocampal synaptosomes from chronic morphine-treated mice. $A$, PKC antagonist chelerythrine (CHE) and agonist PDD inversely modulated adenosine uptake. Left, CHE (5 $\mu \mathrm{m})$ reduced but PDD (500 nm) stimulated the adenosine uptake significantly in hippocampal synaptosomes. Right, Intracerebral injection of CHE (4 $\mu$ g, i.c.v.) and PDD (300 ng, i.c.v.) exhibited the same effects as in vitro. Data are represented as mean \pm SEM $(n=4)$. ${ }^{* *} p<$ 0.01 compared with saline-treated control mice, one-way ANOVA with PLSD post hoc test. $\boldsymbol{B}$, Chronic but not acute morphine treatment significantly inhibited the PKC activity in hippocampal synaptosomes $2 \mathrm{~h}$ after last morphine administration, and this effect could be prevented by concomitant injection of opioid receptor antagonist naltrexone ( $4 \mathrm{mg} / \mathrm{kg}$, i.p.). The upper band indicated unphosphorylated substrates, and the lower band showed the fluorescence of phosphorylated peptides that reflected the activity of PKC. Data are represented as mean \pm SEM $(n=4) .{ }^{* *} p<0.01$ compared with saline-treated control mice; ${ }^{\#} p<0.01$ compared with mice treated with morphine alone, two-way ANOVA test. $\boldsymbol{C}-\boldsymbol{E}$, The time courses of changes in PKC activity, adenosine uptake, and extracellular adenosine concentrations in the hippocampus of chronic morphine-treated mice. Data are represented as mean $\pm \operatorname{SEM}(n=4) .{ }^{*} p<0.05$ compared with saline-treated control mice. ${ }^{* *} p<0.01$ compared with saline-treated control mice, one-way ANOVA with PLSD post hoc test. CTL, Control; MOR, morphine; NAL, naltrexone.

Overall, these results indicate that chronic morphine treatment attenuates PKC activity via downregulation of $\mathrm{PKC}-\alpha / \beta$ but not PKC- $\gamma / \varepsilon$ expression.

Accumulation of extracellular adenosine concentration inhibited hippocampal LTP by activation of $A_{1}$ receptor It has been shown that adenosine inhibits LTP in the hippocampus via activation of adenosine $A_{1}$ receptors (Arai et al., 1990; Alzheimer et al., 1991). In addition, previous studies have shown that hippocampal LTP is reduced by chronic morphine treatment (Pu et al., 2002; Bao et al., 2007). Based on these findings, we therefore determined whether the extracellular adenosine accumulation could contribute to the impairment of LTP by activation of adenosine $A_{1}$ receptors in response to chronic morphine treatment. To do this, we first examined the effect of chronic morphine treatment on hippocampal CA1 LTP by extracellular recording at CA1 area in the hippocampal slices from chronic morphine-treated mice $2 \mathrm{~h}$ after the last morphine administration. In the hippocampal slices from saline-treated mice, highfrequency stimulation of the Schaffer collateral inputs to CA1 pyramidal cells induced a stable LTP (Fig. 6) in the amplitude of fEPSP, which was consistent with a previous report (Xu et al., 1997; Dai et al., 2008). However, as shown in Figure 6B, in the hippocampal slices from chronic morphine-treated mice, LTP induced by high-frequency stimulation was greatly reduced. Twoway ANOVA with between-subjects factors of morphine treatment and high-frequency stimulation revealed a significant effect of morphine treatment $\left(F_{(1,16)}=11.06, p<0.01\right)$, a significant effect of 

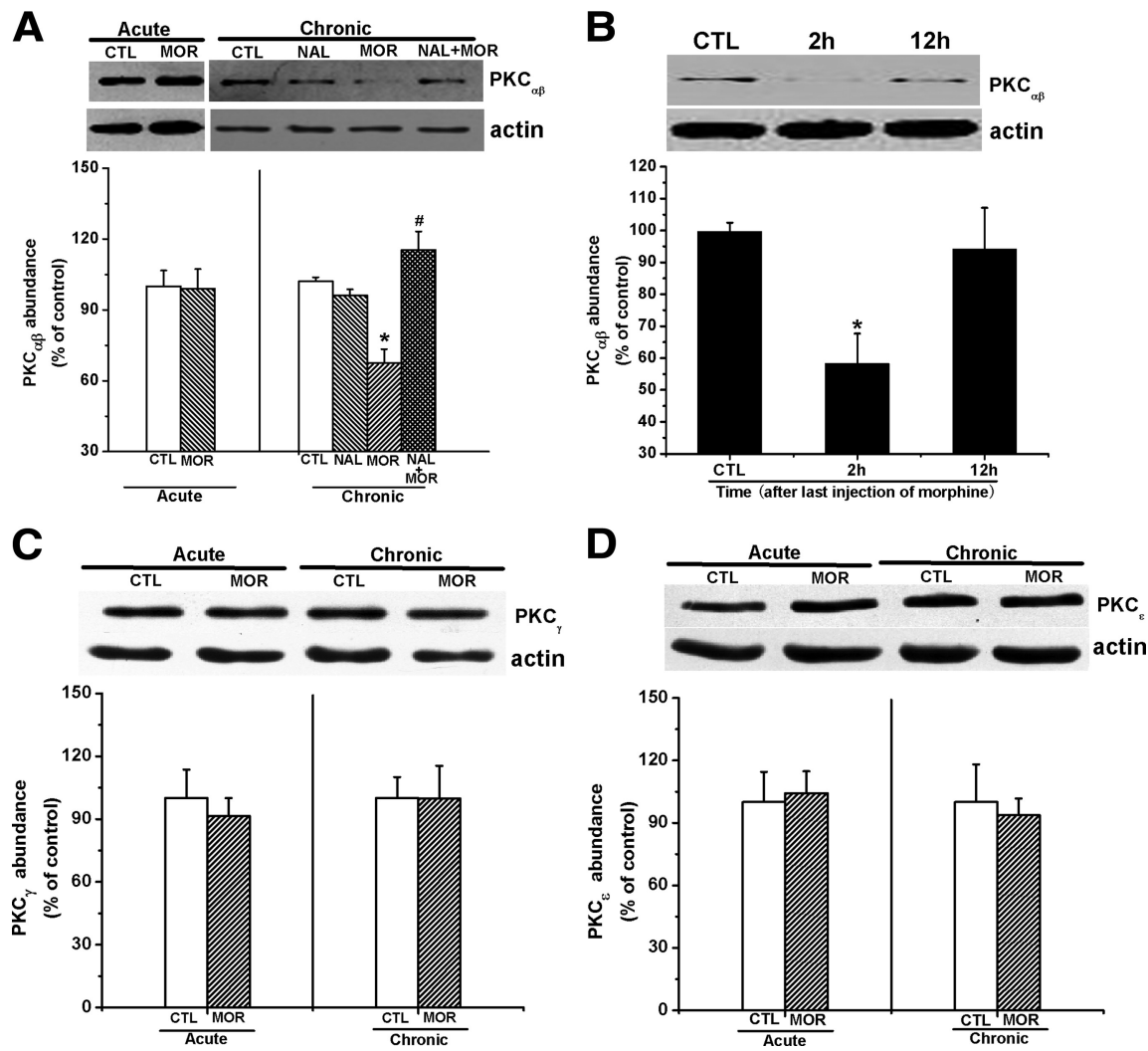

Figure 5. Chronic morphine treatment caused downregulation of PKC $-\alpha / \beta$ but not PKC $-\gamma / \varepsilon$ expression in the hippocampus $2 \mathrm{~h}$ after last morphine administration. $\boldsymbol{A}$, Chronic but not acute morphine treatment significantly inhibited the PKC- $\alpha / \beta$ expres sion $2 \mathrm{~h}$ after last morphine administration, and this effect could be prevented by concomitant injection of opioid receptor antagonist naltrexone (4 mg/kg, i.p.). Data are represented as mean \pm SEM $(n=5)$. ${ }^{*} p<0.05$ compared with saline-treated control mice; ${ }^{\#} p<0.05$ compared with mice treated with morphine alone, two-way ANOVA test. $\boldsymbol{B}$, PKC- $\alpha / \beta$ expression in the hippocampal synaptosomes prepared from chronic morphine-treated mice was restored to the control levels $12 \mathrm{~h}$ after last morphine administration. Data are represented as mean \pm SEM $(n=4)$. ${ }^{*} p<0.05$ compared with saline-treated control mice, one-way ANOVA with PLSD post hoc test. $\boldsymbol{C}, \boldsymbol{D}$, There were no significant alterations of PKC $-\gamma$ and PKC- $\varepsilon$ expressions in the hippocampus from chronic morphine mice $2 \mathrm{~h}$ after last morphine administration. Data are represented as mean $\pm \operatorname{SEM}(n=4)$, Student's $t$ test. CTL, Control; MOR, morphine; NAL, naltrexone.

high-frequency stimulation $\left(F_{(1,16)}=22.04, p<0.001\right)$, and a significant interaction between these two factors $\left(F_{(1,16)}=8.64, p<\right.$ $0.05)$. In contrast, two-way ANOVA for acute morphine treatment with between-subjects factors of morphine treatment and high-frequency stimulation revealed no main effect of morphine treatment $\left(F_{(1,16)}=0.51, p>0.05\right)$ and no significant interaction between these two factors $\left(F_{(1,16)}=0.66, p>0.05\right)$ but showed a significant effect of high-frequency stimulation $\left(F_{(1,16)}=8.29\right.$, $p<0.05$ ) (Fig. 6A). Next, we tested the effects of inclusion of adenosine deaminase $(1 \mathrm{U} / \mathrm{ml})$, a catabolic enzyme of endogenous adenosine, and DPCPX (100 nM), a specific adenosine $A_{1}$ receptor antagonist, in incubating ACSF on the impaired LTP in hippocampal slices from chronic morphine-treated animals. As shown in Figure $6 C$, impaired hippocampal LTP could be restored in the presence of adenosine deaminase in incubating ACSF. Two-way ANOVA with between-subjects factors of morphine treatment and adenosine deaminase treatment revealed a significant interaction between these two factors $\left(F_{(1,20)}=6.75\right.$, $p<0.01)$. Similarly, impaired hippocampal LTP could be reversed significantly in the presence of DPCPX in incubating ACSF. Two-way ANOVA with between-subjects factors of morphine treatment and DPCPX treatment revealed a significant interaction of these two factors $\left(F_{(1,22)}=6.11, p<0.05\right)$ (Fig. $\left.6 D\right)$. These results indicate that extracellular adenosine accumula- tion is crucially involved in chronic morphine-induced impairment of hippocampal CA1 LTP by activation of adenosine $A_{1}$ receptor.

Chronic morphine treatment-induced
accumulation of extracellular
adenosine impaired spatial memory
retrieval via activation of $A_{1}$ receptor
Alteration of hippocampal CA1 LTP in
animals can modulate memory process, as
measured by the Morris water maze (Morris et al., 1986; Moser et al., 1998; Riedel et al., 1999). The functional consequences of adenosine-mediated LTP impairment were thus tested in the Morris water maze. As shown in Figure $7 A$ and $B$, chronic treatment with increasing doses of morphine did not affect the performance of the spatial learning task of mice and also did not attenuate the swim ability in performing the task. A two-way ANOVA with escape latency as repeated measure revealed no main effects of chronic morphine treatment $\left(F_{(1,60)}=\right.$ $0.05, p>0.05)$ or DPCPX treatment $\left(F_{(1,60)}=0.13, p>0.05\right)$ or interaction between these two factors $\left(F_{(1,60)}=0.95\right.$, $p>0.05)$. Two-way ANOVA with swim speed as repeated measure also revealed no significant effects of chronic morphine treatment $\left(F_{(1,60)}=0.84, p>0.05\right)$ or DPCPX treatment $\left(F_{(1,60)}=0.42, p>\right.$ $0.05)$ or interaction between these two factors $\left(F_{(1,60)}=1.02, p>0.05\right)$.

Next, memory retrieval for the previously learned spatial information (platform location) was tested $1 \mathrm{~d}$ after the last training in a free probe trial for $60 \mathrm{~s}$. As shown in Figure $7 C$, mice chronically treated with increasing doses of morphine exhibited an increased initial crossing latency, indicative of impairment of the spatial memory retention. A twoway ANOVA with initial crossing latency as repeated measure revealed no DPCPX effect $\left(F_{(1,60)}=3.82, p>0.05\right)$ but did show a significant effect of chronic morphine treatment $\left(F_{(1,60)}=13.91\right.$, $p<0.01)$ and a significant interaction between these two factors $\left(F_{(1,60)}=18.87, p<0.001\right)$. Post hoc group differences were indicated in Figure $7 C$.

The pattern of effects for quadrant search times was similar to that for initial latency to cross the platform location (Fig. 7E). A two-way ANOVA with quadrant as repeated measure revealed a significant effect of chronic morphine treatment $\left(F_{(1,60)}=13.70\right.$, $p<0.001)$ and a significant interaction between chronic morphine treatment and DPCPX treatment $\left(F_{(1,60)}=5.59, p<0.05\right)$. Post hoc analysis indicated that chronic morphine treatment significantly decreased the time spent in the target quadrant $(p<$ $0.01)$ and that this reduction of quadrant search time was blocked in mice concurrently given DPCPX $\left(0.1 \mathrm{mg} \cdot \mathrm{kg}^{-1}\right.$, i.p. $) 30 \mathrm{~min}$ before the last morphine injection $(p<0.01)$. Figure $7 D$ shows representative swim paths during the probe trial. Overall, these results indicate that chronic exposure to morphine did not impair learning ability of mice, but significantly impaired retrieval 
of spatial memory, consistent with the findings of previous studies ( $\mathrm{Pu}$ et al., 2002; Miladi Gorji et al., 2008).

Chronic exposure to morphine with the equal daily dose regimen also resulted in the impairment of cognitive function through extracellular adenosine accumulation, and this effect was not correlated with withdrawal symptoms Although the results presented above indicate that chronic morphine treatment induces adenosine accumulation via reduction of adenosine uptake, which contributes to the impairment of cognitive function, these observations were based on a single exposure regimen with a high morphine dose on the last several days and a single assessment of cognitive function. To further validate our findings, we assessed adenosine uptake, adenosine accumulation, and cognitive function at different times after exposure to a lower dose of morphine with the equal daily dose regimen and correlated these alterations with the withdrawal symptoms. As shown in Figure $8, A$ and $B$, two-way ANOVA with the between-subjects factors of morphine treatment and time of termination of morphine treatment revealed that chronic treatment of mice with morphine using the equal daily dose regimen $(10 \mathrm{mg} / \mathrm{kg}$, s.c., twice per day) also led to the reduction of $\left[{ }^{3} \mathrm{H}\right]$ adenosine by hippocampal synaptosomes $\left(F_{(1,27)}=11.28, p<0.01\right)$ and the enhancement of extracellular adenosine concentrations in the hippocampal slices $\left(F_{(1,26)}=23.08, p<0.01\right)$. Post hoc tests within each time showed a significant difference for the reduction of adenosine uptake at $2 \mathrm{~h}$ and $7 \mathrm{~d}(p<0.05)$ and elevation of adenosine concentrations at $2 \mathrm{~h}$ and $7 \mathrm{~d}(p<0.01)$, respectively, after last morphine administration.

Correspondingly, as shown in Figure $8 C$, chronic treatment of mice with morphine using the equal daily dose regimen also resulted in a significant increase of initial crossing latency at $2 \mathrm{~h}$ and $7 \mathrm{~d}$ but not $30 \mathrm{~d}$ after last morphine administration. A two-way ANOVA with initial crossing latency as repeated measure revealed no DPCPX effect at $2 \mathrm{~h}\left(F_{(1,77)}=3.40, p>0.05\right), 7 \mathrm{~d}$ $\left(F_{(1,77)}=2.74, p>0.05\right)$, and $30 \mathrm{~d}\left(F_{(1,60)}=2.67, p>0.05\right)$. But this analysis did reveal a significant effect of chronic morphine treatment at $2 \mathrm{~h}\left(F_{(1,77)}=16.14, p<0.001\right)$ and $7 \mathrm{~d}\left(F_{(1,77)}=\right.$ 18.31, $p<0.001)$ but not $30 \mathrm{~d}\left(F_{(1,60)}=2.04, p>0.05\right)$ and a significant interaction between both factors at $2 \mathrm{~h}\left(F_{(1,77)}=4.54\right.$, $p<0.05), 7 \mathrm{~d}\left(F_{(1,77)}=4.52, p<0.05\right)$, and $30 \mathrm{~d}\left(F_{(1,60)}=4.51\right.$, $p<0.05)$. These results indicate that chronic morphine treatment reduced adenosine uptake, increased adenosine concentration, and impaired spatial memory retention via activation of $A_{1}$ receptor.

As shown in Figure 8, $D$ and $E$, mice chronically treated with morphine using the equal daily dose regimen did not spontaneously express spontaneous withdrawal signs before $2 \mathrm{~h}$ or after $36 \mathrm{~h}$ after last morphine administration but did express spontaneous withdrawal signs assessed by jump and by global scores at $8,12,24$, and $36 \mathrm{~h}$ after last morphine administration. Two-way ANOVA analysis
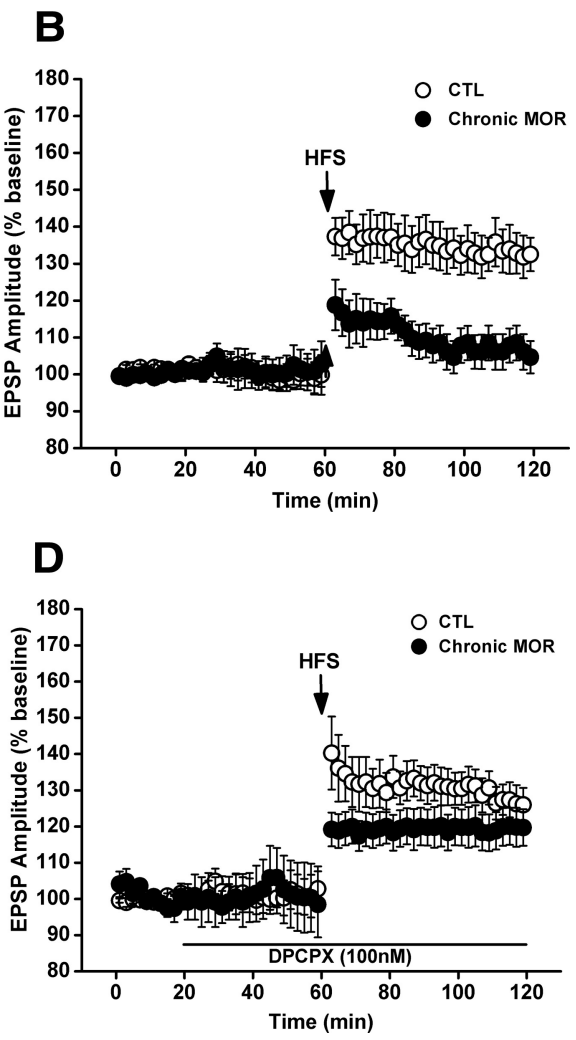

Figure 6. Accumulation of extracellular adenosine concentration inhibited hippocampal CA1 LTP by activation of $\mathrm{A}_{1}$ receptor. $A$, Acute treatment of mice with morphine (100 mg/kg, 1 injection on day 7$)$ failed to impair CA1 LTP in the hippocampal slices derived $\mathrm{m}$ mice $2 \mathrm{~h}$ after morphine administration. $\boldsymbol{B}$, Chronic treatment of mice with increasing doses of morphine for 7 consecutive ment. D, Bath application of $A_{1}$ antagonist DPCPX (100 nM) did not affect the basal synaptic transmission but partially and ent of LTP induction induced by chronic morphine exposure. CTL, Control; MOR, morphine.

revealed a significant interaction of morphine treatment $\times$ time of termination of morphine treatment (for jumps, $F_{(5,72)}=6.19, p<$ 0.001 ; for global scores, $\left.F_{(5,72)}=4.36, p<0.01\right)$. Post hoc group differences are indicated in Figure $8, D$ and $E$. Also, there was no significant difference in adenosine concentrations between the hippocampal slices incubated with or without morphine (data not shown). These findings suggest that the reduction of adenosine uptake, elevation of intracellular adenosine concentrations, and impairment of cognitive function were not correlated with morphine withdrawal reactions. Together, these results support that chronic morphine treatment impairs cognitive function through elevation of hippocampal extracellular adenosine concentrations and that this effect is the consequence of morphine exposure per se rather than of morphine withdrawal.

\section{Discussion}

Extracellular adenosine accumulation contributed to chronic morphine treatment-induced impairment of hippocampal CA1 LTP and spatial memory by acting on adenosine $A_{1}$ receptors

Accumulating evidence has demonstrated that chronic exposure to opiates (e.g., morphine and heroin) diminishes hippocampal CA1 LTP (Pu et al., 2002; Salmanzadeh et al., 2003) and leads to the impairment of acquisition (Spain and Newsom, 1991; Li et al., 2001) or retention (Alaei et al., 2006; Miladi Gorji et al., 2008) of spatial memory. However, the mechanisms underlying these effects of opiates remain unclear. The present study revealed that 

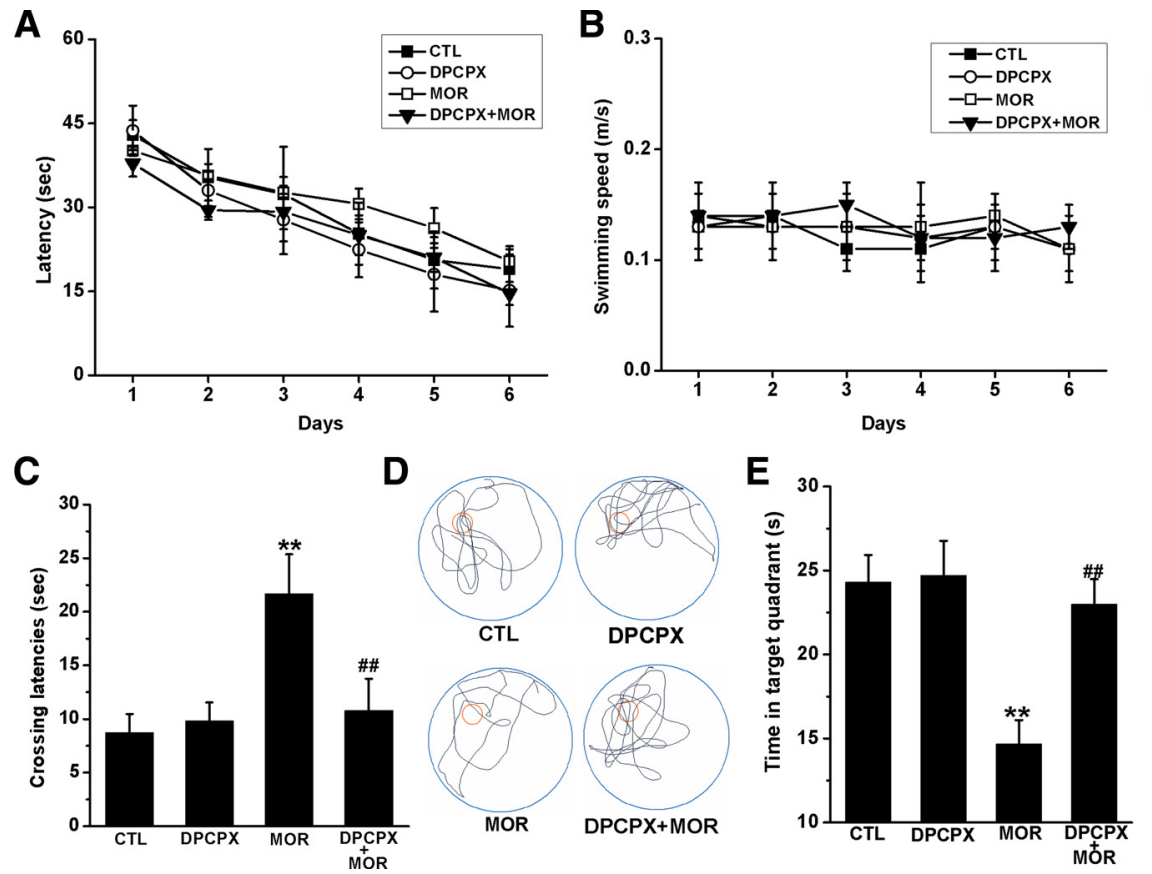

Figure 7. Effect of chronic morphine treatment on the performance of spatial learning and memory task by mice in Morris water maze tests. Mice were treated with increasing doses of morphine for $7 \mathrm{~d}$ as described in Materials and Methods and then were trained and tested in Morris water maze for an additional $7 \mathrm{~d}$. During the period of training and testing, morphine $(100 \mathrm{mg} / \mathrm{kg}$, twice per day) was still injected into mice. On day 14 , a probe trial consisting of a 60 s free swim period without the Perspex platform was performed $2 \mathrm{~h}$ after last morphine or saline injection. $A$, Chronic morphine treatment did not affect the latency to escape onto a hidden platform. $\boldsymbol{B}$, Chronic morphine treatment did not affect swimming speed for performing the task. $\boldsymbol{C}$, Chronic morphine treatment increased initial crossing latencies to the platform on the probe trial day. Data represent the mean $\pm \operatorname{SEM}(n=9)$. ${ }^{* *} p<0.01$ compared with saline-treated control mice; ${ }^{\# \#} p<0.01$ compared with mice treated with morphine alone, two-way ANOVA test. $\boldsymbol{D}, \boldsymbol{E}$, Chronic morphine treatment altered the searching pattern of the mice $(\boldsymbol{D})$ and decreased time spent in the target quadrant when the platform was removed $(\boldsymbol{E})$. Data represent the mean \pm SEM $(n=9)$. ${ }^{* *} p<0.01$ compared with saline-treated control mice; ${ }^{\# \#} p<$ 0.01 compared with mice treated with morphine alone, two-way ANOVA test. CTL, Control; MOR, morphine.

chronic exposure to morphine could diminish hippocampal CA1 LTP and impair spatial memory at least partially through the accumulation of hippocampal extracellular adenosine acting on adenosine $A_{1}$ receptor. This was supported by the observations that adenosine $A_{1}$ receptor antagonist DPCPX significantly restored chronic morphine-induced impairment of hippocampal CA1 LTP and spatial memory. Likewise, adenosine deaminase, which converts adenosine into the inactive metabolite inosine, also significantly restored impaired hippocampal CA1 LTP by the removal of adenosine.

Our results suggest that extracellular adenosine accumulation in the hippocampus was mainly induced by chronic morphine treatment per se rather than by the withdrawal from morphine treatment. This notion is supported by the following evidences. First, acute morphine treatment did not cause hippocampal extracellular adenosine accumulation $2 \mathrm{~h}$ after last morphine administration. Second, significant withdrawal signs that are generally observed after opiate withdrawal were not detected $2 \mathrm{~h}$ and $7 \mathrm{~d}$ after last morphine administration (Figs. 2A, B, 8D,E) (Papaleo and Contarino, 2006; Papaleo et al., 2008), although adenosine accumulation occurred at these two time points after last morphine administration. Third, withdrawal signs were also not observed in the hippocampal slices prepared from chronic morphine-treated mice except that these slices were precipitated by naloxone. Additionally, localized increase of cAMP, which usually occurred upon opiate withdrawal, could not be rapidly converted to adenosine in rat hippocampus (Brundege et al., 1997; Dunwiddie et al., 1997), because of limited capability of ectophosphodiesterases to con- vert cAMP to AMP. Finally, there is evidence that opiate withdrawal restored rather than impaired cognitive function (Spain and Newsom, 1991; Li et al., 2001).

\section{Role of the equilibrative nucleoside transporters in chronic morphine treatment-induced hippocampal extracellular adenosine accumulation} In CNSs, basal extracellular adenosine concentrations probably reflect equilibrium between the formation and removal. Extracellular adenosine originates from released adenine nucleotides by extracellular catabolism via the ecto-nucleotidase pathway, and is removed by adenosine deaminase and adenosine kinase (for a review, see Latini and Pedata, 2001). On the other hand, nucleoside transporters play a crucial role in controlling extracellular adenosine concentrations by either release of intracellular adenosine or uptake of extracellular adenosine, depending on intracellular and extracellular adenosine concentrations. Since intracellular adenosine concentrations are normally low under physiological conditions due to the relatively high activity of intracellular adenosine kinase, nucleoside transports may favor the uptake of extracellular adenosine to reequilibrate its gradient across the cell membrane (Dunwiddie and Masino, 2001).

There are two main categories of nucleoside transports: (1) ENTs, which can be classified as ENT1 and ENT2 based on their sensitivity to the selective inhibitor NBTI, and (2) concentrative nucleoside transporters. ENTs are widely expressed in the brain, including the hippocampus, and play a predominant role in controlling the levels of extracellular adenosine (Latini and Pedata, 2001). We found that treatment with NBTI, a selective inhibitor of ENTs, at micromolar concentrations led to a significant elevation of the extracellular adenosine concentrations in the hippocampal slices from saline-treated animals, whereas this augmentative effect of NBTI was significantly attenuated in the hippocampal slices from morphine-treated mice, indicating that the capability of ENTs (perhaps ENT2) to uptake adenosine was decreased in the hippocampal slices from morphine-treated mice. However, the augmentative effect of NBTI on extracellular adenosine concentrations was not observed at low nanomolar concentrations, indicating that ENT2 may be the predominant nucleoside transporter in the hippocampus, which is consistent with previous findings that ENT2 is the dominant nucleoside transporter in neurons and astrocytes (Sinclair et al., 2000; Parkinson et al., 2005). Moreover, we found that there was no change of activities of the key adenosine metabolic enzymes, such as ecto-5'nucleotidase, which converts AMP to adenosine, adenosine deaminase, which converts adenosine to inosine, and adenosine kinase, which converts adenosine into AMP after chronic morphine treatment. These results clearly indicate that chronic morphine treatment induces the enhancement of hippocampal extracellular adenosine concentrations by the impairment of nu- 
cleoside transporter function but not by the alteration of adenosine metabolisms.

\section{Changes in PKC activity were} correlated with the impairment of the equilibrative nucleoside transporter function in the short-term but not the long-term period after termination of morphine treatment

The function of ENTs can be modulated by PKC (Coe et al., 2002; Huang et al., 2003). There are potential PKC phosphorylation sites in the intracellular hydrophilic loops in both ENT1 and ENT2 (Kiss et al., 2000), which suggests that activities of ENT1 and ENT2 could be modulated by PKC-mediated phosphorylation as described for other transporters. It has been shown that PKC inhibitors dosedependently reduce intracellular uptake of $\left[{ }^{3} \mathrm{H}\right]$ uridine (Huang et al., 2003). And activation of PKC by the nonspecific agonist peptide increases adenosine uptake significantly (Chaudary et al., 2004). Consistent with these studies, we showed that PDD, a specific PKC activator, stimulated but chelerythrine, a specific PKC inhibitor, inhibited adenosine uptake, indicative of PKC modulation of ENT function in the hippocampus of mice (PintoDuarte et al., 2005).

Moreover, we demonstrated that in chronic morphine-treated mice PKC activity was correlated with adenosine uptake at the observed time points $(1,2$, and $12 \mathrm{~h}$ ) after termination of morphine treatment. A significant attenuation of PKC activity was observed at 1 and $2 \mathrm{~h}$ after last morphine administration. Correspondingly, the significant reduction of adenosine uptake and elevation of extracellular adenosine concentrations were also observed at these two time points. In parallel with the restoration of PKC activity at $12 \mathrm{~h}$ after termination of morphine treatment, adenosine uptake and extracellular adenosine concentrations also returned to control levels at this time point. These results suggest that change in PKC activity may be implicated in chronic morphine treatment-induced alteration of ENT2 function. Furthermore, we found that PKC- $\alpha / \beta$ isoforms modulate ENT2 function because downregulation of the expression of PKC- $\alpha / \beta$ but not PKC- $\gamma / \varepsilon$ isoforms paralleled the reduction of PKC activity, adenosine uptake, and enhancement of extracellular adenosine concentration. In support of our findings, previous studies also reported that chronic exposure to opiates led to a significant reduction of $\mathrm{PKC}-\alpha / \beta$ isoform expression in the frontal cortex of the human and rat brains (Busquets et al., 1995; Ventayol et al., 1997). Although the present and previous studies clearly show the downregulation of $\mathrm{PKC}-\alpha / \beta$ isoform expression in brain after chronic morphine treatments, how the reduction of $\mathrm{PKC}-\alpha / \beta$ abundance in hippocampal synaptosome is achieved in the hippocampus by morphine remains unknown. We speculate that there might be at least two possible mechanisms. One is that chronic morphine treatment may alter the translocation of PKC$\alpha / \beta$ by decreasing receptor for activated $\mathrm{C}$ kinase 1 (RACK1) expression (Escribá and García-Sevilla, 1999). RACK1 is crucial
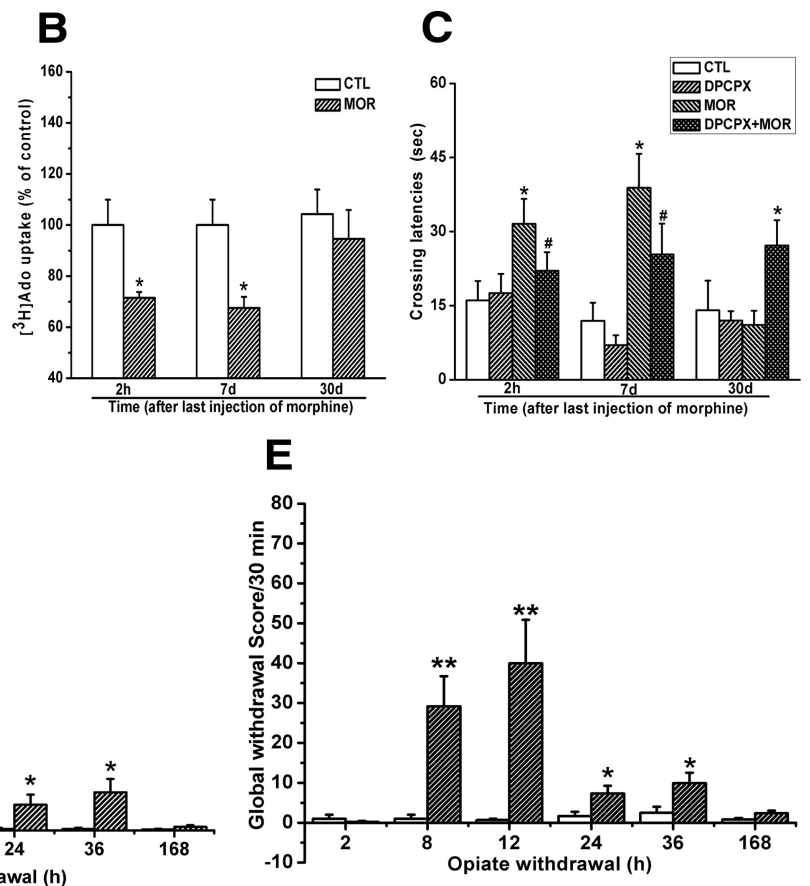

Figure 8. Effects of chronic treatment of mice with equal daily dose of morphine ( $20 \mathrm{mg} / \mathrm{kg}$, twice per day) on adenosine opiate withdrawal signs $8,12,24$, and $36 \mathrm{~h}$ but not $2 \mathrm{~h}$ and $7 \mathrm{~d}$ after the last morphine administration. Data are represented as mean \pm SEM $(n=8) .{ }^{*} p<0.05,{ }^{* *} p<0.01$ compared with saline-treated control mice, two-way ANOVA with PLSD post hoc

for PKC localization and activity (Ron et al., 1995; Pascale et al., 1996). The other is that the alterations of $\mathrm{PKC}-\alpha / \beta$ levels after chronic morphine treatment may be related to the changes in the expression of some immediate early genes (c-fos JunB and $\Delta$ FosB) (Liu et al., 1994; Muller and Unterwald, 2005), which may regulate the expression of $\mathrm{PKC}-\alpha / \beta$ levels.

Distinct from its correlation with the impairment of ENT2 function during early withdrawal from morphine, PKC was not correlated with the impairment of ENT2 function in the longterm period ( $7 \mathrm{~d}$ ) after termination of morphine treatment. The reduction of adenosine uptake and enhancement of extracellular adenosine concentrations were still observed $7 \mathrm{~d}$ after termination of morphine treatment (Fig. $8 A, B$ ), although PKC activity restored at 12 after termination of morphine treatment (Fig. $4 C$ ). One possible interpretation for these data is that the impairment of ENT2 function $7 \mathrm{~d}$ after termination of morphine treatment might be implicated in other protein kinases (e.g., PKA, MAPK, and tyrosine kinase), since these protein kinases have been shown to regulate ENT functions (Coe et al., 1996; Huang et al., 2002, 2003). Alternatively, it is also possible that the reduction of adenosine uptake does not depend on the phosphorylation of ENT2 by protein kinases but is due to the changes in intracellular adenosine levels by unknown mechanisms, leading to the inhibition of ENT function. Further study is needed to address these issues.

\section{Conclusions}

The present study revealed that chronic morphine treatment impaired hippocampal LTP and spatial memory via accumulation 
of extracellular adenosine acting on adenosine $\mathrm{A}_{1}$ receptors. Decreased ENT2 function appeared to play a key role in chronic morphine treatment-induced adenosine accumulation. Our findings extend previous studies by suggesting a novel mechanism underlying impairment of cognitive function by chronic morphine treatment.

\section{References}

Alaei H, Borjeian L, Azizi M, Orian S, Pourshanazari A, Hanninen O (2006) Treadmill running reverses retention deficit induced by morphine. Eur J Pharmacol 536:138-141.

Alzheimer C, Röhrenbeck J, ten Bruggencate G (1991) Adenosine depresses induction of LTP at the mossy fiber-CA3 synapse in vitro. Brain Res 543:163-165.

Arai A, Kessler M, Lynch G (1990) The effects of adenosine on the development of long-term potentiation. Neurosci Lett 119:41-44.

Bao G, Kang L, Li H, Li Y, Pu L, Xia P, Ma L, Pei G (2007) Morphine and heroin differentially modulate in vivo hippocampal LTP in opiatedependent rat. Neuropsychopharmacology 32:1738-1749.

Bliss TV, Collingridge GL (1993) A synaptic model of memory: long-term potentiation in the hippocampus. Nature 361:31-39.

Bonci A, Williams JT (1996) A common mechanism mediates long-term changes in synaptic transmission after chronic cocaine and morphine. Neuron 16:631-639.

Brundege JM, Diao L, Proctor WR, Dunwiddie TV (1997) The role of cyclic AMP as a precursor of extracellular adenosine in the rat hippocampus. Neuropharmacology 36:1201-1210.

Busquets X, Escriba PV, Sastre M, García-Sevilla JA (1995) Loss of protein kinase $\mathrm{C}$-alpha beta in brain of heroin addicts and morphine-dependent rats. J Neurochem 64:247-252.

Chaudary N, Naydenova Z, Shuralyova I, Coe IR (2004) The adenosine transporter, $\mathrm{mENT} 1$, is a target for adenosine receptor signaling and protein kinase Cepsilon in hypoxic and pharmacological preconditioning in the mouse cardiomyocyte cell line, HL-1. J Pharmacol Exp Ther 310:1190-1198.

Chen XL, Lu G, Gong YX, Zhao LC, Chen J, Chi ZQ, Yang YM, Chen Z, Li QL, Liu JG (2007) Expression changes of hippocampal energy metabolism enzymes contribute to behavioural abnormalities during chronic morphine treatment. Cell Res 17:689-700.

Chieng B, Williams JT (1998) Increased opioid inhibition of GABA release in nucleus accumbens during morphine withdrawal. J Neurosci 18:7033-7039.

Cipolli C, Galliani I (1987) Addiction time and intellectual impairment in heroin users. Psychol Rep 60:1099-1105.

Coe I, Zhang Y, McKenzie T, Naydenova Z (2002) PKC regulation of the human equilibrative nucleoside transporter, hENT1. FEBS Lett 517:201-205.

Coe IR, Dohrman DP, Constantinescu A, Diamond I, Gordon AS (1996) Activation of cyclic AMP-dependent protein kinase reverses tolerance of a nucleoside transporter to ethanol. J Pharmacol Exp Ther 276:365-369.

Cunha RA, Almeida T, Ribeiro JA (2000) Modification by arachidonic acid of extracellular adenosine metabolism and neuromodulatory action in the rat hippocampus. J Biol Chem 275:37572-37581.

Dai JX, Han HL, Tian M, Cao J, Xiu JB, Song NN, Huang Y, Xu TL, Ding YQ, Xu L (2008) Enhanced contextual fear memory in central serotonindeficient mice. Proc Natl Acad Sci U S A 105:11981-11986.

Delaney SM, Blackburn GM, Geiger JD (1997) Diadenosine polyphosphates inhibit adenosine kinase activity but decrease levels of endogenous adenosine in rat brain. Eur J Pharmacol 332:35-42.

de Mendonça A, Ribeiro JA (1990) 2-Chloroadenosine decreases long-term potentiation in the hippocampal CA1 area of the rat. Neurosci Lett 118:107-111.

Done C, Silverstone P, Sharp T (1992) Effect of naloxone-precipitated morphine withdrawal on noradrenaline release in rat hippocampus in vivo. Eur J Pharmacol 215:333-336.

Dunwiddie TV, Masino SA (2001) The role and regulation of adenosine in the central nervous system. Annu Rev Neurosci 24:31-55.

Dunwiddie TV, Diao L, Proctor WR (1997) Adenine nucleotides undergo rapid, quantitative conversion to adenosine in the extracellular space in rat hippocampus. J Neurosci 17:7673-7682.

Eisch AJ, Barrot M, Schad CA, Self DW, Nestler EJ (2000) Opiates inhibit neurogenesis in the adult rat hippocampus. Proc Natl Acad Sci U S A 97:7579-7584.
Escribá PV, García-Sevilla JA (1999) Parallel modulation of receptor for activated $\mathrm{C}$ kinase 1 and protein kinase $\mathrm{C}$-alpha and beta isoforms in brains of morphine-treated rats. Br J Pharmacol 127:343-348.

Everitt BJ, Robbins TW (1997) Central cholinergic systems and cognition. Annu Rev Psychol 48:649-684.

Fan GH, Wang LZ, Qiu HC, Ma L, Pei G (1999) Inhibition of calcium/ calmodulin-dependent protein kinase II in rat hippocampus attenuates morphine tolerance and dependence. Mol Pharmacol 56:39-45.

Fiorillo CD, Williams JT (2000) Selective inhibition by adenosine of mGluR IPSPs in dopamine neurons after cocaine treatment. J Neurophysiol 83:1307-1314.

Forghani R, Krnjević K (1995) Adenosine antagonists have differential effects on induction of long-term potentiation in hippocampal slices. Hippocampus 5:71-77.

Guerra D, Solé A, Camí J, Tobeña A (1987) Neuropsychological performance in opiate addicts after rapid detoxification. Drug Alcohol Depend 20:261-270.

Hack SP, Vaughan CW, Christie MJ (2003) Modulation of GABA release during morphine withdrawal in midbrain neurons in vitro. Neuropharmacology 45:575-584.

Huang KP, Nakabayashi H, Huang FL (1986) Isozymic forms of rat brain $\mathrm{Ca} 2+$-activated and phospholipid-dependent protein kinase. Proc Natl Acad Sci U S A 83:8535-8539.

Huang M, Wang Y, Collins M, Gu JJ, Mitchell BS, Graves LM (2002) Inhibition of nucleoside transport by p38 MAPK inhibitors. J Biol Chem 277:28364-28367.

Huang M, Wang Y, Cogut SB, Mitchell BS, Graves LM (2003) Inhibition of nucleoside transport by protein kinase inhibitors. J Pharmacol Exp Ther 304:753-760.

Hyman SE, Malenka RC, Nestler EJ (2006) Neural mechanisms of addiction: the role of reward-related learning and memory. Annu Rev Neurosci 29:565-598.

Ingram SL, Vaughan CW, Bagley EE, Connor M, Christie MJ (1998) Enhanced opioid efficacy in opioid dependence is caused by an altered signal transduction pathway. J Neurosci 18:10269-10276.

Jaken S, Kiley SC (1987) Purification and characterization of three types of protein kinase C from rabbit brain cytosol. Proc Natl Acad Sci U S A 84:4418-4422.

Kelley AE, Bakshi VP, Fleming S, Holahan MR (2000) A pharmacological analysis of the substrates underlying conditioned feeding induced by repeated opioid stimulation of the nucleus accumbens. Neuropsychopharmacology 23:455-467.

Kiss A, Farah K, Kim J, Garriock RJ, Drysdale TA, Hammond JR (2000) Molecular cloning and functional characterization of inhibitor-sensitive (mENT1) and inhibitor-resistant (mENT2) equilibrative nucleoside transporters from mouse brain. Biochem J 352:363-372.

Latini S, Pedata F (2001) Adenosine in the central nervous system: release mechanisms and extracellular concentrations. J Neurochem 79:463-484.

Ledent C, Valverde O, Cossu G, Petitet F, Aubert JF, Beslot F, Böhme GA, Imperato A, Pedrazzini T, Roques BP, Vassart G, Fratta W, Parmentier M (1999) Unresponsiveness to cannabinoids and reduced addictive effects of opiates in CB1 receptor knockout mice. Science 283:401-404.

Li HB, Mao RR, Zhang JC, Yang Y, Cao J, Xu L (2008) Antistress effect of TRPV1 channel on synaptic plasticity and spatial memory. Biol Psychiatry 64:286-292.

Li YQ, Li FQ, Wang XY, Wu P, Zhao M, Xu CM, Shaham Y, Lu L (2008) Central amygdala extracellular signal-regulated kinase signaling pathway is critical to incubation of opiate craving. J Neurosci 28:13248-13257.

Li Z, Wu CF, Pei G, Xu NJ (2001) Reversal of morphine-induced memory impairment in mice by withdrawal in Morris water maze: possible involvement of cholinergic system. Pharmacol Biochem Behav 68:507-513.

Liu J, Nickolenko J, Sharp FR (1994) Morphine induces c-fos and junB in striatum and nucleus accumbens via D1 and N-methyl-D-aspartate receptors. Proc Natl Acad Sci U S A 91:8537-8541.

Lu L, Zeng S, Liu D, Ceng X (2000) Inhibition of the amygdala and hippocampal calcium/calmodulin-dependent protein kinase II attenuates the dependence and relapse to morphine differently in rats. Neurosci Lett 291:191-195.

Maldonado R, Blendy JA, Tzavara E, Gass P, Roques BP, Hanoune J, Schütz G (1996) Reduction of morphine abstinence in mice with a mutation in the gene encoding CREB. Science 273:657-659.

Matthes HW, Maldonado R, Simonin F, Valverde O, Slowe S, Kitchen I, 
Befort K, Dierich A, Le Meur M, Dollé P, Tzavara E, Hanoune J, Roques BP, Kieffer BL (1996) Loss of morphine-induced analgesia, reward effect and withdrawal symptoms in mice lacking the mu-opioid-receptor gene. Nature 383:819-823.

Miladi Gorji H, Rashidy-Pour A, Fathollahi Y (2008) Effects of morphine dependence on the performance of rats in reference and working versions of the water maze. Physiol Behav 93:622-627.

Morris RG, Anderson E, Lynch GS, Baudry M (1986) Selective impairment of learning and blockade of long-term potentiation by an N-methyl-Daspartate receptor antagonist, AP5. Nature 319:774-776.

Moser EI, Krobert KA, Moser MB, Morris RG (1998) Impaired spatial learning after saturation of long-term potentiation. Science 281:2038-2042.

Muller DL, Unterwald EM (2005) D1 dopamine receptors modulate $\Delta$ fosB induction in rat striatum after intermittent morphine administration. J Pharmacol Exp Ther 314:148-154.

Narita M, Aoki T, Ozaki S, Yajima Y, Suzuki T (2001) Involvement of protein kinase Cgamma isoform in morphine-induced reinforcing effects. Neuroscience 103:309-314.

Nestler EJ, Aghajanian GK (1997) Molecular and cellular basis of addiction. Science 278:58-63.

Newton PM, Kim JA, McGeehan AJ, Paredes JP, Chu K, Wallace MJ, Roberts AJ, Hodge CW, Messing RO (2007) Increased response to morphine in mice lacking protein kinase C epsilon. Genes Brain Behav 6:329-338.

Nishizuka Y (1988) The molecular heterogeneity of protein kinase $C$ and its implications for cellular regulation. Nature 334:661-665.

Papaleo F, Contarino A (2006) Gender- and morphine dose-linked expression of spontaneous somatic opiate withdrawal in mice. Behav Brain Res 170:110-118.

Papaleo F, Ghozland S, Ingallinesi M, Roberts AJ, Koob GF, Contarino A (2008) Disruption of the $\mathrm{CRF}(2)$ receptor pathway decreases the somatic expression of opiate withdrawal. Neuropsychopharmacology 33:2878-2887.

Parkinson FE, Xiong W, Zamzow CR (2005) Astrocytes and neurons: different roles in regulating adenosine levels. Neurol Res 27:153-160.

Pascale A, Fortino I, Govoni S, Trabucchi M, Wetsel WC, Battaini F (1996) Functional impairment in protein kinase $\mathrm{C}$ by RACK1 (receptor for activated C kinase 1) deficiency in aged rat brain cortex. J Neurochem 67: 2471-2477.

Pinto-Duarte A, Coelho JE, Cunha RA, Ribeiro JA, Sebastião AM (2005) Adenosine A2A receptors control the extracellular levels of adenosine through modulation of nucleoside transporters activity in the rat hippocampus. J Neurochem 93:595-604.

Pu L, Bao GB, Xu NJ, Ma L, Pei G (2002) Hippocampal long-term potentiation is reduced by chronic opiate treatment and can be restored by reexposure to opiates. J Neurosci 22:1914-1921.

Rezayof A, Zarrindast MR, Sahraei H, Haeri-Rohani A (2003) Involvement of dopamine receptors of the dorsal hippocampus on the acquisition and expression of morphine-induced place preference in rats. J Psychopharmacol 17:415-423.

Riedel G, Micheau J, Lam AG, Roloff EL, Martin SJ, Bridge H, de Hoz L,
Poeschel B, McCulloch J, Morris RG (1999) Reversible neural inactivation reveals hippocampal participation in several memory processes. Nat Neurosci 2:898-905.

Robbins TW, Everitt BJ (1999) Drug addiction: bad habits add up. Nature 398:567-570.

Ron D, Luo J, Mochly-Rosen D (1995) C2 region-derived peptides inhibit translocation and function of $\mathrm{b}$ protein kinase $\mathrm{C}$ in vivo. J Biol Chem 270:24180-24187.

Salmanzadeh F, Fathollahi Y, Semnanian S, Shafizadeh M (2003) Dependence on morphine impairs the induction of long-term potentiation in the CA1 region of rat hippocampal slices. Brain Res 965:108-113.

Shoji Y, Delfs J, Williams JT (1999) Presynaptic inhibition of GABA(B)mediated synaptic potentials in the ventral tegmental area during morphine withdrawal. J Neurosci 19:2347-2355.

Sinclair CJ, LaRivière CG, Young JD, Cass CE, Baldwin SA, Parkinson FE (2000) Purine uptake and release in rat C6 glioma cells: nucleoside transport and purine metabolism under ATP-depleting conditions. J Neurochem 75:1528-1538.

Smith FL, Gabra BH, Smith PA, Redwood MC, Dewey WL (2007) Determination of the role of conventional, novel and atypical PKC isoforms in the expression of morphine tolerance in mice. Pain 127:129-139.

Spain JW, Newsom GC (1991) Chronic opioids impair acquisition of both radial maze and Y-maze choice escape. Psychopharmacology (Berl) 105:101-106.

Thorn JA, Jarvis SM (1996) Adenosine transporters. Gen Pharmacol 27:613-620.

Ventayol P, Busquets X, Garcia-Sevilla JA (1997) Modulation of immunoreactive protein kinase $\mathrm{C}$-alpha and beta isoforms and $\mathrm{G}$ proteins by acute and chronic treatments with morphine and other opiate drugs in rat brain. Naunyn Schmiedebergs Arch Pharmacol 355:491-500.

Von Lubitz DK, Paul IA, Bartus RT, Jacobson KA (1993) Effects of chronic administration of adenosine $\mathrm{A} 1$ receptor agonist and antagonist on spatial learning and memory. Eur J Pharmacol 249:271-280.

Ward H, Baldwin D, Wang T, Warner H, Seymour K, Marquardt C, McFalls E, Foker JE (1998) Ion-exchange column chromatographic method for assaying purine metabolic pathway enzymes. J Chromatogr B Biomed Sci Appl 707:295-300.

Xu L, Anwyl R, Rowan MJ (1997) Behavioural stress facilitates the induction of long-term depression in the hippocampus. Nature 387:497-500.

Xu NJ, Yu YX, Zhu JM, Liu H, Shen L, Zeng R, Zhang X, Pei G (2004) Inhibition of SNAP-25 phosphorylation at Ser 187 is involved in chronic morphine-induced down-regulation of SNARE complex formation. J Biol Chem 279:40601-40608.

Yang J, Han H, Cao J, Li L, Xu L (2006) Prenatal stress modifies hippocampal synaptic plasticity and spatial learning in young rat offspring. Hippocampus 16:431-436.

Zhang JM, Wang HK, Ye CQ, Ge W, Chen Y, Jiang ZL, Wu CP, Poo MM, Duan S (2003) ATP released by astrocytes mediates glutamatergic activity-dependent heterosynaptic suppression. Neuron 40:971-982. 